This document is the Accepted Manuscript version of a Published Work that appeared in final form in:

Magrach A., Champetier A., Krishnan S., Boreux V., Ghazoul J. 2019. Uncertainties in the value and opportunity costs of pollination services. JOURNAL OF APPLIED ECOLOGY. 56. (7) 1549-1559. DOI (10.1111/1365-2664.13399).

(C) 2019 British Ecological Society

Page 1 of 51

\title{
Uncertainties in the value and opportunity costs of pollination services
}

2

3 Ainhoa Magrach ${ }^{1,2,{ }^{*} a}$, Antoine Champetier ${ }^{3, *}$, Smitha Krishnan $^{1,4}$, Virginie Boreux ${ }^{1,5}$

$$
\text { Jaboury Ghazoul }{ }^{1}
$$

$6{ }^{1}$ Ecosystem Management, Institute of Terrestrial Ecosystems, Department of

7 Environmental Systems Science, ETH Zürich, Universitätstrasse 16, 8092 Zürich,

8 Switzerland

$9{ }^{2}$ Basque Centre for Climate Change-BC3, Edif. Sede 1, 1 , Parque Tecnológico UPV,

10 Barrio Sarriena s/n, 48940, Leioa, Spain +34 944014690 ext 168

$11{ }^{3}$ Institute for Environmental Decisions, Department of Environmental Systems

12 Science, ETH Zürich

$13{ }^{4}$ Ashoka Trust for Research in Ecology and the Environment (ATREE), Bangalore

$14 \quad 560064$, India

$15{ }^{5}$ Department of Nature Conservation and Landscape Ecology, University of Freiburg,

16 Tennenbacherstr. 4, 79106 Freiburg, Germany

17

$18 *$ These authors contributed equally

$19{ }^{a}$ Corresponding author

20 Ainhoa Magrach ainhoamagrach@hotmail.com 
23

24

\section{Abstract}

1. Pollination is an ecosystem service that directly contributes to agricultural production, and can therefore provide a strong incentive to conserve natural habitats that support pollinator populations. However, we have yet to provide consistent and convincing pollination service valuations to effectively slow the conversion of natural habitats.

2. We use coffee in Kodagu, India, to illustrate the uncertainties involved in estimating costs and benefits of pollination services. First, we fully account for the benefits obtained by coffee agroforests that are attributable to pollination from wild bees nesting in forest habitats. Second, we compare these benefits to the opportunity cost of conserving forest habitats and forgoing conversion to coffee production. Throughout, we systematically quantify the uncertainties in our accounting exercise and identify the parameters that contribute most to uncertainty in pollination service valuation.

3. We find the value of pollination services provided by one hectare of forest to be $25 \%$ lower than the profits obtained from converting that same surface to coffee production using average values for all parameters. However, our results show this value is not robust to moderate uncertainty in parameter values, particularly that driven by variability in pollinator density.

4. Synthesis and applications. Our findings emphasise the need to develop robust estimates of both value and opportunity costs of pollination services that take into account landscape and management variables. Our analysis contributes to strengthening pollination service arguments used to help stakeholders make informed decisions on land-use and conservation practices. 
49 Coffee, crop pollination, ecosystem services, forest, opportunity cost, sensitivity 50 analysis, valuation

51 Resumen (Abstract in Spanish)

1. La polinización es un servicio ecosistémico que contribuye directamente a la productividad agrícola, y que, por tanto, puede suponer un incentivo para conservar los hábitats naturales que albergan poblaciones de polinizadores. Sin embargo, aún no somos capaces de establecer valoraciones consistentes y convincentes de los servicios de polinización que sirvan para frenar la conversión de hábitats naturales.

2. En este artículo, usamos el cultivo de café en el distrito de Kodagu en India beneficios de los servicios de polinización. En primer lugar, contabilizamos los beneficios obtenidos en sistemas agroforestales de café que son atribuibles a la polinización por abejas silvestres que anidan en hábitats forestales. En segundo lugar, comparamos estos beneficios con los costes de oportunidad relativos a conservar hábitats forestales al renunciar a la conversión a la producción de café. A lo largo de todo el proceso, cuantificamos sistemáticamente la incertidumbre asociada con nuestro ejercicio de contabilidad e identificamos los parámetros que más contribuyen a la incertidumbre en la valoración del servicio de polinización.

3. Encontramos que, usando valores medios para todos los parámetros, el valor de los servicios de polinización generados por una hectárea de bosque es un $25 \%$ más bajo que el beneficio obtenido al convertir esa misma superficie a la producción de café. Sin embargo, nuestros resultados demuestran que este 
valor no es robusto a una incertidumbre moderada en los valores de los parámetros, en particular relacionada con la variabilidad en la densidad de polinizadores.

4. Sintesis y aplicaciones: Nuestros resultados destacan la necesidad de desarrollar estimas robustas tanto del valor como del coste de oportunidad asociado con los servicios de polinización que tengan en cuenta variables del paisaje y del tipo de manejo. Nuestro análisis contribuye a fortalecer los argumentos sobre los servicios de polinización usados para ayudar a que los diferentes actores involucrados tomen decisiones informadas sobre las prácticas de conservación y el uso de la tierra. (1)

\section{Introduction}

Natural ecosystems are exposed to pressures that threaten their biodiversity (Butchart et al., 2010) and the ecosystem services they provide (Díaz et al., 2006). Ecosystem services (ES) are often used to highlight links between conservation and human well-being, as more diverse ecosystems are often considered better providers of ES (Cardinale et al., 2012). Thus, ES are increasingly being used as an argument for biodiversity conservation (Chan et al., 2011).

Pollination is an essential ES linking natural habitats to agricultural landscapes, as $70 \%$ of crop species depend to some extent on pollinators (Klein et al., 2007). Yet, many pollinators are exposed to threats that are driving population 4 declines (Vanbergen \& The Insect Pollinators Initiative, 2013), such as pesticides, 5 diseases (Potts et al., 2010) or habitat destruction due to land use change (Winfree et 6 al., 2009). The conversion of natural habitats to agricultural land causes the loss of 97 nesting and foraging resources for pollinators, and ultimately leads to a decline in 
pollinator activity, with potentially serious consequences for crop production (Kremen et al., 2002).

In many farming systems, pollinator scarcity might be overcome by direct pollination management practices, such as renting beehives. For smallholder farmers in the tropics who mainly depend on wild pollinators for crop productivity, this is rarely an option. In those cases, crop pollination services can be valued as the difference between crop profits when wild pollinators provide services, and crop profits with diminished pollinator availability due to habitat loss, for instance. Yet, obtaining consistent valuations of natural habitat as a provider of crop pollination services has proved challenging (Melathopoulos et al., 2015; Winfree et al., 2011).

Two approaches can be used to quantify the value of pollination services. The first one involves the calculation of the cost of replacement using alternative pollination sources (e.g., bee hives, hand-pollination, pollen dusting) (e.g., Allsopp et al., 2008). In coffee, replacement is often difficult, given the loss of many domestic bee colonies to pest and diseases (e.g., in India with Apis cerana, Boreux et al., 2013). The second, and most frequently used approach, consists of calculating the increase in crop productivity that results from effective pollination by wild pollinators as compared to no, or reduced, pollination (e.g., Losey \& Vaughan 2006; Olschewski et al., 2007). Many of the studies following such approach have relied on the relationship between pollinator visitation rates and distance from habitat (Ricketts et al., 2004). Improvements of this method increase the precision in accounting for production costs, and adjust these costs to production losses in the absence of pollinators, further distinguishing between the contributions of managed and

121 unmanaged bees (Winfree et al., 2011). 
However, contributions using both approaches have an important limitation

123 for the support of ES as a conservation argument: they generally only calculate

124 benefits brought by pollination services originating in nearby natural habitats, and

125 thus neglect the opportunity cost of maintaining those habitats rather than converting

126 them to other valuable uses. A second limitation lies in the lack of uncertainty

127 measures for estimated values (Olander et al., 2017) and a robust management of the

128 inherent variability and complexity of pollination processes in complex landscapes.

129 These shortcomings may help explain why the pollination service conservation

130 argument is not effectively reaching decision-makers in developing countries, despite

131 the growth in academic research focusing on pollination services in the 15 years since

132 the seminal paper by Ricketts and Taylor (2004).

Here, we develop an accounting of costs and benefits for pollination services

134 provided to coffee production. Coffee is one the most valuable tropical export crops

135 with a production that has steadily increased during the past decades (FAOstat, 2018);

136 and for which expansion has been done at the expense of forested areas (Meyfroidt et

137 al., 2014). Coffee is also a crop for which pollination biology and agricultural

138 practices are well known (De Beenhouwer et al., 2013; Vandermeer \& Perfecto, 2012;

139 Vergara \& Badano, 2009), and thus represents a good model crop species to illustrate

140 the uncertainties in estimating the costs and benefits of pollination services.

141 Specifically, our study seeks (i) to fully account for the benefits accruing to

142 coffee agroforests that are attributable to pollination from wild bees nesting in forest

143 habitats, (ii) to compare these benefits to the opportunity cost of converting forest

144 habitats to coffee production, and (iii) to apply systematic sensitivity analysis to

145 quantify the uncertainty in the accounting exercise, while identifying which of the

146 parameters included in the calculations contribute most to output uncertainty. 
147 Although our model does not explicitly track pollinator diffusion in space and the 148 related problem of coordination among farmers, we argue that we can address the 149 need for robust pollination valuation more effectively by sorting and prioritizing 150 uncertainty and complexity in pollination processes.

\section{Materials and Methods}

Our study focuses on Robusta coffee, Coffea canephora Pierre ex Froehner, in the agroforestry systems of Kodagu, Karnataka State, in the Western Ghats in India. The Western Ghats is a global biodiversity hotspot within one of the world's megadiverse countries, India (Myers et al., 2000). The district of Kodagu displays a gradient of land covers from primary contiguous forest, to a mix of remnant forest fragments which comprise $46 \%$ of the territory, diverse agro-forests covering $32.5 \%$ of the area where $C$. canephora is the main crop ( $72 \%$ of all the coffee produced in the area in 2009, Coffee Board, 2014); with the rest being occupied by water bodies $(0.5 \%)$ and other crops (including paddy $21 \%)$. Coffee agroforests are shaded either by a diverse community of native tree species, a monoculture of the fast growing Australian species Grevillea robusta (silver oak) or more often a mix of the two in varying proportions. G. robusta now accounts for $20 \%$ of shade tree individuals in the area (French Institute of Pondicherry, 2012), the result of a rapid adoption driven by low seedling and pruning costs, periodic timber sales (which do not involve elaborate procedures to obtain rights to fell trees as is the case for native trees), and its suitability as trellis for pepper plants, the second major crop within coffee estates (Garcia et al., 2010).

In the study area, coffee is mainly pollinated by three social bee species: Apis dorsata, Apis cerana indica and Tetragonula iridipennis which account for 58\%, 
$17123.4 \%$ and $18 \%$ of the visits respectively, the remaining $0.5 \%$ performed by Apis

172 florea (Krishnan et al., 2012). Pollination by insects increases fruit set by up to 50\%

173 (increasing the proportion of flowers that develop into fruits from $22 \%$ when

174 pollinated by wind only to $33 \%$ when wind and insects are combined, Krishnan et al.,

175 2012). The persistence of Apis cerana is not strictly dependent on natural forests, as it

176 can nest within tree-holes and termite mounds, also present in coffee agroforests.

177 Furthermore, domesticated $A$. cerana hives are actively managed in some coffee

178 estates (Boreux et al., 2013). Tetragonula iridipennis prefer to nest in old man-made

179 structures and tree holes in coffee agroforests, as well as in forests. In contrast, $A$.

180 dorsata depend largely on the occurrence of large trees in which they nest, and these

181 trees are mostly found in forest patches, although occasionally, also in agroforests

182 (Pavageau et al., 2018). The activity of $A$. dorsata within coffee agroforests is

183 influenced by both distance to the nearest forest and size of the forest (Boreux et al.,

184 2013). The data available on the distribution and abundance of $T$. iridipennis and $A$.

185 cerana in relation to forest cover is very scarce, and mostly collected through ground

186 surveys, which could increase the possibility of missing colonies located in tree

187 canopies (Krishnan unpublished data). We therefore focus our analyses on the main

188 forest-dependent wild pollinator in the study area, A. dorsata, which accounts for the

189 large majority of flower visits, and is a more effective pollinator than the other two

190 species (Krishnan et al., 2012).

191 Accounting of Cost and Revenues of Coffee Production

192 We develop an accounting model- both economic and ecological- of pollination

193 services provided by $A$. dorsata bees from native forests. We compare the opportunity

194 costs of conserving native forests in terms of forgone coffee production, against the

195 value of the pollination services that such forests provide. This quantitative 
comparison is useful to a landowner facing the decision of conserving or converting a forest remnant. The owners of most of the private forest fragments in the study area are farmers, and it is mainly privately-owned forest fragments that have undergone conversion to coffee cultivation (Garcia et al., 2010). Therefore, we use agronomic accounting standards used by farmers and extension services around the world, and coffee production cost and coffee revenues as the focus of our model. We are careful to account for pepper and timber revenues, as these are known to be important to farmers in the area. Finally, we use Monte Carlo simulations to track sources of uncertainty in our estimates by implementing a systematic analysis of sensitivity to parameter values.

We obtained data from three sources: interviews conducted with local farmers, ecological data from previous studies (Boreux et al., 2013; Boreux et al., 2013; Krishnan et al., 2012; World Agroforestry Centre, 2011) and other published literature (e.g., (Wintgens, 2004)).

Farmer interviews were conducted during April 2014 in 34 farms located in the vicinity of Virajpet in Kodagu $\left(12^{\circ} 12^{\prime} 02.55^{\prime \prime} \mathrm{N} 75^{\circ} 47^{\prime} 59.90^{\prime \prime} \mathrm{E}\right)$. Fifteen of these farms had silver oak (G. robusta) cover exceeding $30 \%$ of all shade trees and are therefore considered "exotic" agroforests. The rest had lower values of silver oak and are considered "native" agroforests. Each farmer was questioned about the characteristics of their farm (size, types of crops planted, number of coffee plants, tree shade species identity and abundance), coffee production, the production of other crops (e.g. pepper or bananas), amount and type of timber sold per year, profits obtained from coffee and from other products (other crops and timber), as well as a detailed accounting of the estate management costs (e.g. shade tree pruning, manure or fertilizer application etc., summarized as cultural costs in Table 1). 
Using standard agronomic accounting, we calculate the economic returns of two alternative uses of one hectare of natural forest: (i) conservation of native forest for pollination services and (ii) conversion of forest to coffee production. For a comparable accounting of initial investments and costs or benefits accruing over the lifetime of a coffee agroforest, we calculated net present values

226 (NPVs). We assumed a 50-year horizon to match the maximum productive lifetime of 227 coffee trees, with discount rates ranging from 2 to $8 \%$ (Moore et al., 2004). In coffee 228 production, revenues accrue from selling coffee, pepper and timber. Production costs 229 arise from the use of labour and agricultural inputs. We estimated values for both 230 exotic (those where shade tree cover by the exotic species G. robusta exceeds $30 \%$ )

231 and native coffee systems (those where exotic shade tree cover $<30 \%$ ), and with and 232 without irrigation (one of the most important inputs in this area, Boreux et al., 2013). 233 Pepper and timber profits are higher in exotic systems as G. robusta trees provide 234 better trellis for pepper vines, and state regulations permit harvesting of exotic trees 235 but not native species.

236 NPV for coffee production is calculated as the sum of the present values (PVs) 237 of coffee $\left(P V_{R \text { sat. }}\right)$ at its maximum production value and non-coffee revenues $\left(P V_{N C R}\right.$ 238 ) (all based on 2014 values reported in interviews) minus the present value of total 239 costs $\left(P V_{T C}\right)$ :

$$
N P V_{\text {coffee }}=P V_{R \text { sat. }}+P V_{N C R}-P V_{T C}
$$

$242 P V_{R \text { sat. }}$ can be broken into base coffee production (without biotic pollination,

$\left.243 P V_{R \text { base }}\right)$ and production attributable to pollination $\left(P V_{R \text { attrib. }}\right)$ using the relationship 244 between both found in previous studies (Krishnan et al., 2012): 


$$
P V_{R \text { sat. }}=P V_{R \text { base }}+P V_{R \text { attrib. }}
$$

247 In turn, $P V_{N C R}$ is the present value of non-coffee revenues (NCR), includes pepper and

248 timber revenues for exotic species and accrues every year of the 50-year period:

$$
P V_{N C R}=N C R * D_{1 \text { to } 50}
$$

where $D_{1 \text { to } 50}$ converts a yearly cash flow for years 1 through 50 discounted into a present value. Discount factors are calculated as sums of R terms of geometric series:

$$
D_{1 \text { to } 5}=\frac{1-R^{5}}{1-R}, D_{6 \text { to } 50}=\frac{R^{5}-R^{50}}{1-R} \text { and } D_{1 \text { to } 50}=\frac{1-R^{50}}{1-R}
$$

where $\mathrm{R}$ is:

$$
R=\frac{1}{1-I_{r}}
$$

and $I_{r}$ is the discount rate, which is fixed for the lifetime of the plantation and drawn

260 from a beta distribution. We use the notation for discount factors $D_{i \text { to } j}$ in the rest of

261 the section.

The term $P V_{T C}$ represents total costs and includes establishment costs $(E C)$,

263 cultural costs for the first five years when coffee is not yet productive $\left(C C_{1}\right)$ as well as

264 for years 6 to 50 when coffee becomes productive $\left(C C_{2}\right.$, Table 1$)$ :

267 While many cultural costs are mostly independent from coffee yield, a few cost items

268 are related to yield. Harvest costs may vary with yield, and to a lesser extent fertilizer 269 and irrigation costs. Given the lack of detailed information to establish these 
270 relationships we assume that costs are fixed, an assumption that is shown to have

271 limited potential consequences on estimates by our sensitivity analysis (see Results

272 section).

273 Present values for base production $\left(P V_{R \text { base }}\right)$ and that attributable to pollination

$274\left(P V_{R \text { attrib. }}\right)$ are simply discounted sums of yearly revenues:

275

276

$$
P V_{R \text { base }}=Y_{\text {base }} * P_{r} * D_{6 \text { to } 50}
$$

$$
P V_{R \text { attrib. }}=Y_{\text {attrib. }} * P_{r} * D_{6 \text { to } 50}
$$

where $Y_{\text {base }}$ and $Y_{\text {attrib. }}$ are the yearly coffee yields for base production and

$$
Y_{\text {sat. }}=T_{h} * F_{t} * F S_{\text {sat. }} * B_{w} *\left(1-F_{\text {drop }}\right) / 1000
$$

$Y_{\text {attrib. }}=Y_{\text {sat. }}-Y_{\text {base }}$

where $T_{h}$ is the number of coffee trees/ha, $F_{t}$ the number of flowers/tree. $F S_{\text {no.p }}$ pollination) and $F S_{\text {sat. }}$ fruit-set with pollination. $B_{w}$ represents berry weight (in grams per berry) and $F_{\text {drop }}$ fruit drop of initial fruit set (Table 2). $Y_{\text {sat. }}$ is coffee yield at

293 pollination saturation, which in this case is determined by the maximum fruit set 294 obtained in interviews to farmers. The difference between base and saturated yield 
295 values is the yield attributable to insect pollination $\left(Y_{\text {attrib. }}\right)$. The division by a

296 thousand converts grams into kilograms to obtain yields in kilograms per hectare.

Calculation of benefits of forest conservation through production increase

attributable to pollination

In forest, we account for the value of pollination services provided to visits to the yield produced at pollination saturation in monetary terms (Fig. 1). Here, we calculated NPVs as a function of the number of visits to coffee plants provided by the main pollinator for coffee in the study region, $A$. dorsata and the effect of these visits in terms of yield increment. Thus, NPV of forests is calculated as per:

310 surface saturated by the visits from one hectare of forest habitat and which is given 
where $H$ represents the number of $A$. dorsata hives within forest fragments, $I_{h}$ the

324 number of individuals/hive, $A_{h}$ the percent of foraging individuals, $T r_{d}$ the number of 325 trips/day/worker bee, $D_{\text {open }}$ the days flowers remain receptive and $F l_{T r}$ the number of 326 coffee flowers visited/foraging trip. $V_{\text {sat. fl }}$ represents the number of pollinator visits 327 required to saturate a flower with pollen (Table 2). In the case of forest, we have not 328 included any conservation costs because most forest fragments in the area are 329 privately owned and do not directly entail costs to the owner comparable to the ones 330 included in the coffee calculations (i.e., there are no yearly expenses related to the 331 conservation of forest in the area).

Sensitivity analyses

We performed sensitivity analyses to identify the model parameters that 334 contribute most to uncertainty. We use the Latin hypercube sampling generating 3351,000 sets of parameter values. Each parameter value is drawn from an independent 336 distribution as specified in Tables 1 and 2. We use rescaled beta distributions for 337 parameters that are bounded on an interval, such as ratios. For parameters that are not 338 bounded, such as a price, or a yield, we use truncated normal distributions in order to 339 rule out negative values. The minimum, maximum, mean and standard deviations, 340 which we obtain from different sources as indicated in the tables, are sufficient to 341 parameterise each distribution. For each model, we generated the cumulative 342 distribution of all model results based on the combination of values of all parameters, 343 as well as means, quartiles and other statistics of the distributions. We also calculated 
344 the partial rank correlations coefficients (PRCCs) as indicators of the contribution of

345 one parameter to model output uncertainty, reflecting the importance of that

346 parameter in the model and the variance of the distribution of this parameter. We

347 calculated the PRCCs as the correlation between an input/parameter and model output,

348 controlling for the linear effect of all other inputs. We computed the Pearson

349 correlation coefficient between an input and the residuals of an OLS linear regression

350 of the output on all other inputs. We also calculated PRCCs for the ratio of forest to

351 best coffee NPV in order to enter all parameters into the same uncertainty calculation

352 to be able to compare their different contributions to uncertainty. This ratio also

353 summarizes the comparison of NPVs for forest and coffee agroforests.

354 Finally, we created scatterplots showing the distribution of all model values in

355 the parameter space sampled by the Latin hypercube showing the sensitivity of model

356 results to the variation in each of the parameters. The value for each parameter is

357 assumed to be constant over the lifetime of the agroforest.

358 Results

359 Using average values and other best available estimates for the value of 360 agroecological parameters, we found exotic shade/irrigated coffee had the highest 361 NPV (28.5K EUR/Ha), followed by native shade/irrigation (18.3K EUR/Ha). These 362 discounted profits for coffee production fall on each side of the NPV attributable to 363 pollination services provided by the conservation of forest as habitat for pollinators 364 (21.6K EUR/Ha, vertical dotted lines in Fig. 2). However, the ratio NPVs of forest 365 and shade/irrigated coffee showed a value of $0.75 \pm 26.6$ (mean \pm standard deviation), 366 reflecting that pollination services may not have on average a higher NPV than the 367 best coffee alternative but that uncertainty remains very large. 
Sensitivity analyses confirm that the ranking of NPV values was not robust to error propagation when parameter values were allowed to vary over reasonable ranges determined by the variability in each of the parameters. Indeed, the distribution of

371 NPVs for forest conservation showed a wide range of values (boxplots in Fig. 2), 372 which considerably overlap with the distributions of the four coffee alternatives.

373 Forest conservation was potentially a better economic option than some coffee 374 agroforest regimes at low NPVs $(<30 \mathrm{~K})$ but the probability that forest will provide 375 NPVs $>30 \mathrm{~K} \mathrm{EUR/Ha} \mathrm{is} \mathrm{lower} \mathrm{than} \mathrm{for} \mathrm{coffee} \mathrm{(Fig.} \mathrm{2).}$

The PCCRs for NPVs of coffee production reveal that the parameters 377 contributing the most to uncertainty are fruit drop and fruit set excluding insect 378 pollination, although most parameters have an important contribution (Fig. 3a). 379 Establishment costs (EC in the figure) and cultural costs before maturity (CC1) of 380 coffee were less important contributors to uncertainty as is expected for a 50 -year 381 horizon with moderate discount. The uncertainty in the value of pollination services 382 from forests was mainly driven by hive density per hectare $(\mathrm{H})$ and the proportion of 383 fruits dropped (Fdrop). Results from PCCRs for the ratio of forest to best coffee NPV (Figure 3b, 385 Table S1, Fig. S2) showed that beehive densities per hectare of forest $(\mathrm{H})$ and fruit 386 drop (Fdrop) are the two largest sources of uncertainty in the value of the ratio. Fruit 387 set without pollination (Fsnop), flowers per tree(Fltr), trips per day (TRd), days 388 during which flowers are open (Dopen), and the interest rate (Ir) contribute to 389 uncertainty to a lesser extent. The other parameters hardly contribute to the 390 uncertainty in the ratio either because the ratio calculation cancels off their effect on 391 forest and coffee NPVs (e.g. the coffee price or discount rate), or because they have a 392 small impact on either value in the first place (e.g. establishment costs, Fig.S4-S9). 
393

394

395

396

397

398

399

400

401

402

403

404

405

406

407

408

409

410

411

412

413

\section{Discussion}

The notion that pollination services could justify biodiversity conservation is a topic of current debate, although the initial impetus for the validity of this argument is being questioned (Kleijn et al., 2015). Our results indicate that evaluating the economic benefits of pollination services, and the opportunity costs of conserving pollinator habitat, is highly context-dependent and sensitive to several variables. Quantifying a monetary value for some ES is often necessary to conceptualise the benefits of these services, but it is important to recognize the uncertainties in their calculation (Silvertown, 2018).

We find large disparities in modelled economic values for coffee, despite the fact that coffee pollination is well studied (e.g., Klein et al. 2003b; Ricketts et al. 2004; Krishnan et al. 2012; Boreux et al. 2013a), and that we understand the effect of farm-scale management practices on this service (Boreux et al., 2013). Previous studies suggested that heterogeneity in valuation outcomes might be explained by differences in the estimates of pollinator dependence ratio or market prices (Breeze et al., 2016). This is not the case here, as we have accurate field data on pollinator dependence (Krishnan et al., 2012) and local market prices, as well as a good understanding of management effects (Boreux et al., 2013). Moreover, our study accounts for variables that limit the value of the pollination service, (e.g., fruit drop and resource limitation, Bos et al., 2007) as fruit production is calculated as the number of mature fruits at the end of the season. Despite these advantages, we are still unable to provide a value of pollination services with a high degree of confidence. While previous studies conducted sensitivity analyses to validate the robustness of their pollination service valuations, these included upper and lowerbound values for only two parameters (Bauer \& Sue Wing, 2016). Our study accounts 
418 for all 19 parameters measured. Considering all these sources of uncertainty, we show

419 the importance of understanding the local dynamics of ES before being able to

420 generate confident value estimates.

421 Pollination represents an example of a locally sourced and consumed ES that

422 could aid in the local conservation of habitats by directly linking the service to locally

423 realised economic benefits. This is, however, challenged if we are not able to clarify

424 the actual economic benefit of pollination when set in the full context of agricultural

425 management practices.

426 At present, given our analyses, the NPV of forest conservation for crop

427 pollination services is not clearly different to the NPV of irrigated coffee production

428 with exotic shade cover. Yet while there are substantial risks for negative returns in

429 all coffee scenarios given the high costs associated to coffee production, there are

430 none for forest as there are no direct annual costs related to forest conservation.

We acknowledge that our study is subject to significant caveats aside from

432 data precision. Since we have no information on the current level of pollination

433 saturation in the area, we assume that the current yields, used as reference in our 434 parameter values, correspond to full saturation. Furthermore, we calculate average 435 values of pollination visits assuming a linear effect until saturation. Every visit before 436 saturation brings the same increase in fruit set and corresponding returns, while all 437 visits after saturation bring no yield increase. This stepwise linear response to 438 pollination visits captures the non-linearity generally observed but fails to capture 439 more complex patterns such as more progressive saturation. However, this 440 simplification is not critical since average values are sufficient to support the notion 441 that forest and coffee values are too uncertain to rank with confidence. 
Our analyses focus on a single species, A. dorsata, and ignore the contribution

443 of forests to the maintenance of the other two forest-dependent species, Tetragonula

444 iridipennis and few feral colonies of Apis cerana. However, this should not be greatly

445 affecting the value we give to forests as providers of pollination because the

446 dependence of T. iridipennis and A.cerana on forests for nesting is much lower than

447 that of $A$. dorsata. In previous surveys, we found 356 colonies of $A$. dorsata within

448 forest ecosystems, while we located only 5 T. iridipennis and 23 A. cerana colonies

449 using ground surveys in the same region (Krishnan unpublished data). Therefore, $T$.

450 iridipennis and A. cerana do not seem to be constrained by the extent of forest, since

451 they also found suitable nesting sites in tree holes and termite mounds or old man

452 made structure within coffee agroforests.

453 Further, our model does not represent yearly variability and important features

454 such as farmers' management of production or price risk. In fact, the uncertainty of

455 parameters in our analysis does not distinguish between what is inherent variability

456 (e.g. price is largely determined outside the area of the study) and what is actual lack

457 of knowledge (e.g. the number of $A$. dorsata nests in a given forest patch). Our

458 analysis is also based on the data provided for a single year, which represents a

459 typical "boom" year in coffee production, in which coffee prices were on average 10-

$46020 \%$ higher than those reported the previous and next years (ICO, 2014).

461 Furthermore, we assume that pollination services are the same for all coffee

462 plants regardless of their location. This might overestimate the value of pollination

463 services in some cases. Indeed, pollinators generally show a visitation rate that decays

464 with distance from the nest (Ricketts et al., 2004). In some spatial configurations this

465 could result in saturation in coffee plants near nest habitat and no visitation far away.

466 Heterogeneities in the distribution of forest patches could potentially introduce added 
uncertainty in our analysis, if coffee production responds to the local density of forests. The coffee landscape in Kodagu has, however, a relatively high density of

469 forest fragments throughout the landscape, with a forest remnant every $3 \mathrm{~km}^{2}$ of the 470 land area (Bhagwat et al., 2005), and substantial tree cover within many agroforests.

471 Moreover, the large majority of coffee agroforests are well within the foraging range 472 of $A$. dorsata (Pavageau et al., 2018). We therefore do not expect substantially 473 different responses of further forest loss among areas of relatively low or high 474 existing forest cover.

$475 \quad$ Focusing on average pollinator-flower densities, visitation rates, and resulting 476 economic outcomes, we avoid the sizeable challenges of spatially-explicit modelling, 477 although we are aware that pollination is essentially a spatial process. Indeed, a 478 general analysis of the spatial patterns in the optimal landscape is likely unnecessary 479 since we find that the uncertainty in non-spatial parameters already curtails our ability 480 to rank land uses. The distributions of visits and services in space and their possible 481 heterogeneity can be relevant but are unlikely to be as important as management 482 practices, e.g. the use of irrigation (Pavageau et al., 2018). It remains that an explicit 483 spatial accounting exercise exploring the impact of different diffusion assumptions 484 and parameter values on the uncertainty of NPVs represents a useful extension to our 485 analyses.

486 Another limitation of our analysis stems from our economic and agronomic 487 model being based only on NPV criteria. Land use decisions and adoption of 488 agroecological practices are complex behaviours involving many factors (Burton, 489 2004; Edwards-Jones, 2006) such as: risk attitudes towards investment (Binswanger, 490 1980), access to market or farmer's knowledge of alternative practices (DeFries et al., 491 2004). Our accounting exercise helps identify the information needed to support the 
492 claim that internalizing pollination externalities might contribute to forest 493 conservation. Yet, we must acknowledge that the calculation of NPVs is only one 494 early step in the implementation of the ES argument as a conservation tool (Chan et 495 al., 2012).

Finally, our analysis only accounts for pollination services. Forests provide several other services (e.g., carbon storage, pest control) that might greatly increase their value (Ninan \& Inoue, 2013). Nonetheless, the main objective of this study was to identify the extent to which we can, with present knowledge, assign robust

500 economic values to pollination services provided by natural ecosystems. The

501 conclusion is that it is very difficult to do so in view of multiple confounding factors

502 and associated uncertainties. However, making tangible the trade-off between

503 ecosystem service value and opportunity cost is particularly pressing in view of the 504 global continued conversion of forestland to crop production.

505 Data accessibility

506 Data available via the Dryad Digital Repository https://doi.org/10.5061/dryad.7f14jt7 $507 \quad$ (Magrach et al 2019)

508 Authors' contributions

509 AM, AC and JG conceived the ideas and designed methodology; AM, SK and VB 510 collected the data; AM and AC analysed the data; AM and AC led the writing of the 511 manuscript. All authors contributed critically to the drafts and gave final approval for 512 publication.

\section{Acknowledgements}

514 A.M. acknowledges funding from the ETH Foundation and the Juan de la Cierva 515 Incorporación program (IJCI-2014-22558). We thank C. Garcia and P. Vaast for 516 comments during the preparation of the manuscript. We thank Owen Lewis and an

517 anonymous reviewer for comments and suggestions that have greatly improved our 518 paper. 
520 Table 1. Accounting Parameter symbols, values, and sources.

\begin{tabular}{|c|c|c|c|c|c|c|c|c|}
\hline Parameter & \multicolumn{3}{|l|}{ Description } & Mean & Max & Min & SD & $\begin{array}{l}\text { Distribution, } \\
\text { Source }\end{array}$ \\
\hline $\operatorname{Pr}$ & \multicolumn{3}{|c|}{ Coffee price (EUR/kg) } & 0.93 & 1.13 & 0.73 & 0.11 & $\begin{array}{l}\text { TN, Interviews, } \\
\text { Coffee board } \\
\text { (2014) }\end{array}$ \\
\hline \multirow[t]{4}{*}{$\mathrm{E}_{\mathrm{C}}$} & \multirow{4}{*}{$\begin{array}{l}\text { Establishm } \\
\text { ent costs }\end{array}$} & \multirow[t]{2}{*}{ Native } & No irrigation & 124.83 & + Inf & 0 & 31.21 & \multirow{13}{*}{ TN, Interviews } \\
\hline & & & Irrigation & $1,646.08$ & $+\operatorname{Inf}$ & 0 & 411.52 & \\
\hline & & Exotic & No irrigation & 124.83 & $+\operatorname{Inf}$ & 0 & 31.21 & \\
\hline & & & Irrigation & $1,243.29$ & + Inf & 0 & 310.82 & \\
\hline \multirow{4}{*}{$\mathrm{C}_{\mathrm{C} 1}$} & \multirow{4}{*}{$\begin{array}{l}\text { Cultural } \\
\text { costs years } \\
1-6 \text { (per } \\
\text { year) }\end{array}$} & \multirow{2}{*}{ Native } & No irrigation & $1,196.26$ & $+\mathrm{Inf}$ & 0 & 299.07 & \\
\hline & & & Irrigation & $1,252.43$ & $+\operatorname{Inf}$ & 0 & 313.11 & \\
\hline & & \multirow[t]{2}{*}{ Exotic } & No irrigation & $1,040.03$ & $+\operatorname{Inf}$ & 0 & 260.01 & \\
\hline & & & Irrigation & $1,068.03$ & $+\operatorname{Inf}$ & 0 & 267.01 & \\
\hline \multirow{4}{*}{$\mathrm{C}_{\mathrm{C} 2}$} & \multirow{4}{*}{$\begin{array}{l}\text { Cultural } \\
\text { costs years } \\
6-50 \text { (per } \\
\text { year) }\end{array}$} & \multirow[t]{2}{*}{ Native } & No irrigation & $1,233.69$ & $+\operatorname{Inf}$ & 0 & 308.42 & \\
\hline & & & Irrigation & $1,289.86$ & $+\operatorname{Inf}$ & 0 & 322.46 & \\
\hline & & \multirow{2}{*}{ Exotic } & No irrigation & $1,143.17$ & $+\operatorname{Inf}$ & 0 & 285.79 & \\
\hline & & & Irrigation & $1,171.17$ & + Inf & 0 & 292.79 & \\
\hline \multirow[t]{2}{*}{ NCR } & \multirow{2}{*}{\multicolumn{2}{|c|}{ Non-coffee revenues }} & Native & 387.47 & 800 & 0 & 100.00 & \\
\hline & & & Exotic & 557.03 & 800 & 0 & 100.00 & \\
\hline $\mathrm{Ir}$ & \multicolumn{3}{|c|}{ Discount rate (\%) } & 5.0 & 8.0 & 3.0 & 1.0 & RB, Moore 2004 \\
\hline
\end{tabular}

521 Note: For distributions, TN stands for truncated normal and RB for a rescaled beta distribution. "+Inf" stands for "infinite" and indicates that the 
527 Table 2. Agroecological parameter symbols, values, and sources.

\begin{tabular}{|c|c|c|c|c|c|c|c|c|}
\hline Parameter & \multicolumn{3}{|l|}{ Description } & Mean & Max & Min & SD & Distribution, Source \\
\hline \multirow[t]{2}{*}{ Th } & \multirow{2}{*}{\multicolumn{2}{|c|}{ Number of coffee shrubs per ha }} & Exotic & 1160.71 & 1250 & 1125 & 36.08 & \multirow[t]{2}{*}{$\mathrm{TN}$, Interviews } \\
\hline & & & Native & 1178.85 & 1500 & 1062.50 & 126.29 & \\
\hline $\mathrm{Ft}$ & \multicolumn{3}{|c|}{ Number of flowers per coffee shrub } & 25,000 & 30,000 & 20,000 & 2,000 & RB, (Wintgens, 2004) \\
\hline $\mathrm{D}_{\text {open }}$ & \multicolumn{3}{|c|}{$\begin{array}{l}\text { Days flowering. Coffee flowering is triggered by the first rains } \\
\text { at the end of the dry season, and flowers remain receptive for } \\
\text { around two days. Flowering following rainfall occurs } \\
\text { synchronously across all affected plantations in the landscape. }\end{array}$} & 2 & 3 & 1 & 0.5 & RB, (Boreux et al., 2013) \\
\hline \multirow{4}{*}{$\mathrm{Fs}_{\text {no.p }}$} & \multirow{4}{*}{$\begin{array}{l}\text { Fruit set no pollination } \\
\text { (only wind) }\end{array}$} & \multirow[t]{2}{*}{ Native } & No irrigation & 0.17 & 0.52 & 0.11 & 0.118 & \multirow{12}{*}{ TN, (Krishnan et al., 2012) } \\
\hline & & & Irrigation & 0.21 & 0.55 & 0.17 & 0.110 & \\
\hline & & \multirow[t]{2}{*}{ Exotic } & No irrigation & 0.17 & 0.41 & 0.16 & 0.072 & \\
\hline & & & Irrigation & 0.23 & 0.52 & 0.20 & 0.096 & \\
\hline \multirow[t]{4}{*}{$\mathrm{Fs}_{\text {sat }}$} & \multirow{4}{*}{$\begin{array}{l}\text { Fruit set with pollination } \\
\text { (wind+insect) }\end{array}$} & \multirow[t]{2}{*}{ Native } & No irrigation & 0.08 & 0.16 & 0.01 & 0.024 & \\
\hline & & & Irrigation & 0.11 & 0.22 & 0.01 & 0.033 & \\
\hline & & \multirow[t]{2}{*}{ Exotic } & No irrigation & 0.08 & 0.16 & 0.01 & 0.024 & \\
\hline & & & Irrigation & 0.13 & 0.26 & 0.01 & 0.039 & \\
\hline \multirow[t]{4}{*}{$\mathrm{B}_{\mathrm{w}}$} & \multirow[t]{4}{*}{ Berry weight (grams) } & \multirow[t]{2}{*}{ Native } & No irrigation & 0.39 & 0.57 & 0.31 & 0.075 & \\
\hline & & & Irrigation & 0.42 & 0.55 & 0.32 & 0.066 & \\
\hline & & \multirow[t]{2}{*}{ Exotic } & No irrigation & 0.36 & 0.53 & 0.35 & 0.05 & \\
\hline & & & Irrigation & 0.42 & 0.49 & 0.35 & 0.04 & \\
\hline $\mathrm{F}_{\mathrm{d}}$ & \multicolumn{3}{|c|}{ Proportion of fruits dropped } & 0.31 & 0.1 & 0.9 & 0.21 & RB, (Boreux, 2010) \\
\hline $\mathrm{H}$ & \multicolumn{3}{|c|}{ Number of $A$. dorsata hives per forest ha } & 3.05 & 18 & 0.10 & 5.17 & $\begin{array}{l}\text { TN, (Krishnan, 2011; Pavageau } \\
\text { et al., 2018) }\end{array}$ \\
\hline $\mathrm{I}_{\mathrm{h}}$ & \multicolumn{3}{|c|}{ Number of $A$. dorsata individuals per hive } & 68,300 & 100,000 & 36,600 & 18,302 & $\begin{array}{l}\text { TN, (Corlett, 2011; Dyer \& } \\
\text { Seeley, 1991; Paar, Oldroyd, } \\
\text { Huettinger, \& Kastberger, } \\
\text { 2004) }\end{array}$ \\
\hline$A_{h}$ & \multicolumn{3}{|c|}{$\begin{array}{l}\text { Proportion of foraging individuals per hive. There are no exact } \\
\text { values for } A \text {. dorsata, so we use data for a species in the same } \\
\text { genus }(A \text {. florea })\end{array}$} & 0.17 & 0.23 & 0.1 & 0.037 & TN, (Dyer \& Seeley, 1991) \\
\hline
\end{tabular}




\begin{tabular}{|c|c|c|c|c|c|c|}
\hline $\operatorname{Tr}_{\mathrm{d}}$ & $\begin{array}{l}\text { Number of foraging trips per day per individual assuming } \\
\text { activity occurs } 8 \text { AM and } 5 \text { PM (Krishnan, 2011) Worker bees } \\
\text { are normally active for a maximum of } \sim 9 \text { hours each day } \\
\text { (Krishnan, 2011), and each worker has been estimated to } \\
\text { undertake } 1 \text { foraging visit/day }\left(T r_{d}\right) \text { (Dyer \& Seeley, 1991). } \\
\text { Workers of Apis florea are reported to undertake as many as six } \\
\text { foraging visits/day (Dyer \& Seeley, 1991). Owing to } \\
\text { uncertainties regarding these estimates, we used both values to } \\
\text { calculate the mean number of visits per day }\end{array}$ & 3.5 & 6 & 1 & 1 & RB, (Dyer \& Seeley, 1991) \\
\hline $\mathrm{Fl}_{\mathrm{tr}}$ & $\begin{array}{l}\text { \# Flowers visited per trip. There are no data on the number of } \\
\text { coffee flowers that } A \text {. dorsata visits in each foraging trip, } \\
\text { although results from Asian cotton in India suggest that each } \\
\text { worker might visit up to } 94 \text { flowers/foraging trip (Jones, 2005), } \\
\text { and studies on Apis mellifera suggest they visit up to } 100 \\
\text { flowers/trip (Frankel \& Galun, 1977). }\end{array}$ & 94 & 200 & 20 & 51.96 & $\begin{array}{l}\text { TN, (Frankel \& Galun, 1977; } \\
\text { Jones, 2005) }\end{array}$ \\
\hline $\mathrm{V}_{\text {sat.fl }}$ & $\begin{array}{l}\text { Number of pollinator visits required to saturate a flower with } \\
\text { pollen. Coffee flowers contain two ovules which, when } \\
\text { fertilized, produce two coffee beans, known as a 'cherry' fruit. } \\
\text { Insufficient pollination results in a 'peaberry' in which one of } \\
\text { the seeds is aborted and only one bean develops (Wintgens, } \\
\text { 2004). In the case of } C \text {. canephora, flowers are self-sterile and } \\
\text { therefore successful pollination requires that pollen be sourced } \\
\text { from a different plant. In theory this could be achieved with a } \\
\text { single bee visit, though usually several pollinator visits are } \\
\text { required to successfully deliver viable cross pollen } \\
\text { (Rosenzweig, Cunningham, \& Wirthensohn, n.d.). Given this } \\
\text { uncertainty we used values of one and two visits required for } \\
\text { full fruit set to account for this uncertainty. }\end{array}$ & 1 & 2 & 1 & & \\
\hline
\end{tabular}

Note: For distributions, TN stands for truncated normal and RB for a rescaled beta distribution 
529

530

531

532

533

534

535

536

537

538

539

540

541

542

543

544

545

546 Fruit drop $\left(F_{\text {drop }}\right)$, fruit set without pollination $\left(F s_{n o p}\right)$,cultural costs for years six to 50

547 when coffee becomes productive $(\mathrm{CC} 2)$, berry weight $(\mathrm{Bw})$, hive density per hectare

$548(H)$, price of coffee $(\operatorname{Pr})$, interest rate $(I r)$, flowers per tree $\left(F L_{t r}\right)$, number of coffee

549 trees/ha (Th), fruit set attributable to pollination (Fsatt), revenues from pepper and

550 othe non-coffee products (NCR), number of flowers/tree (Ft), number of visits

551 required to saturate one flower (Vsatfl), trips per day $\left(T R_{d}\right)$, days during which

552 flowers are open $\left(D_{\text {open }}\right)$, cultural costs for the first five years when coffee is not yet 
553 productive (CC1), Number of individuals in Apis dorsata hives (Ih), individuals of a

554 colony foraging at a given moment (Ah), establishment costs (EC)

555

556

557

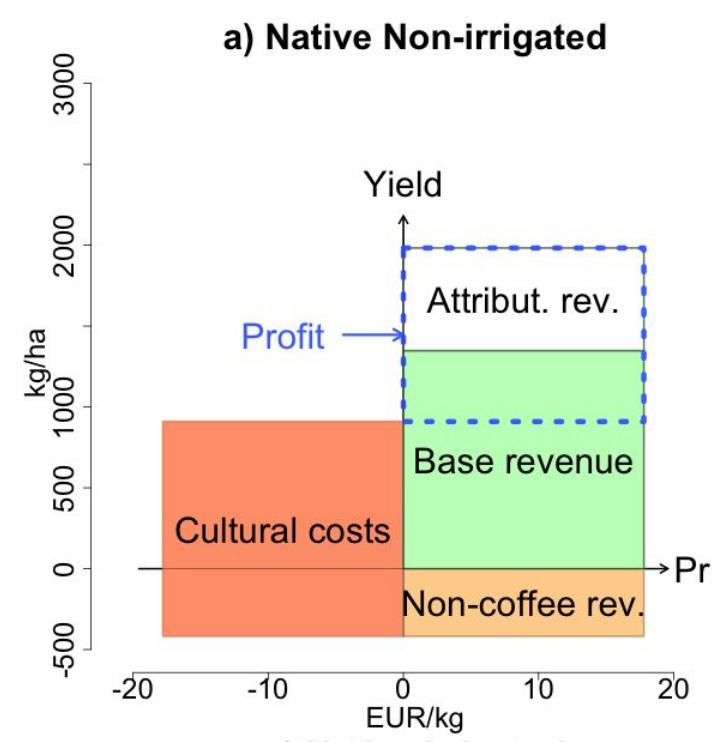

c) Native Irrigated

558

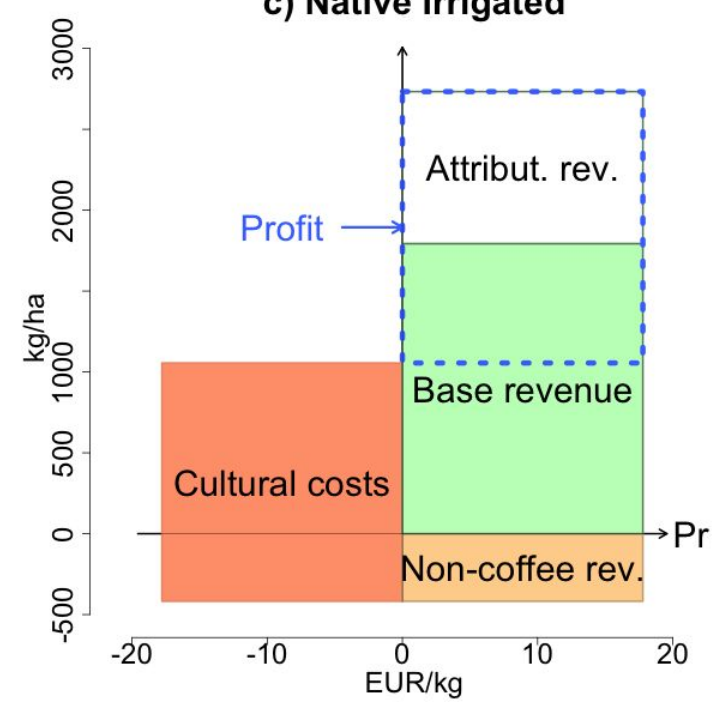

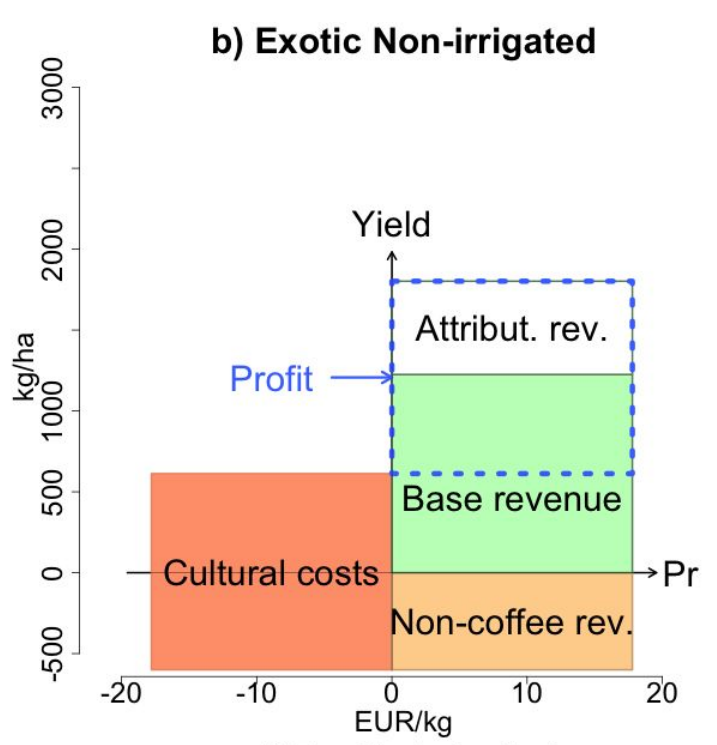

d) Exotic Irrigated

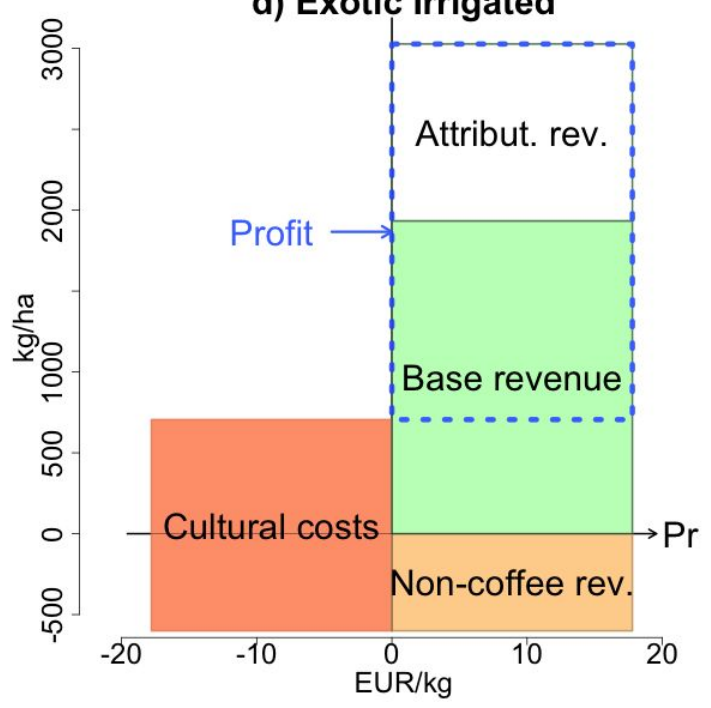

Figure 1. 
560

561

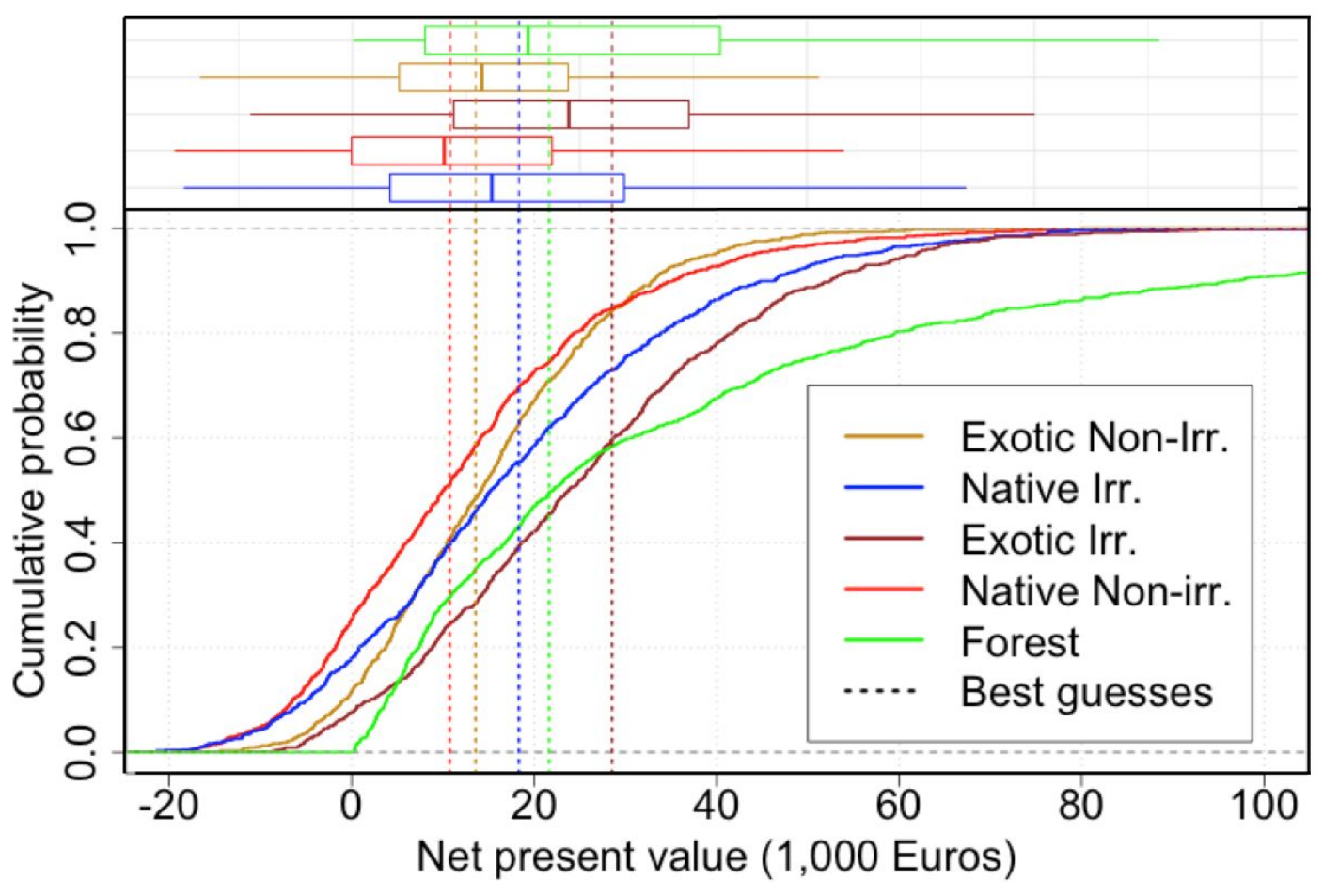

562

Figure 2.

564 
565

566

a)

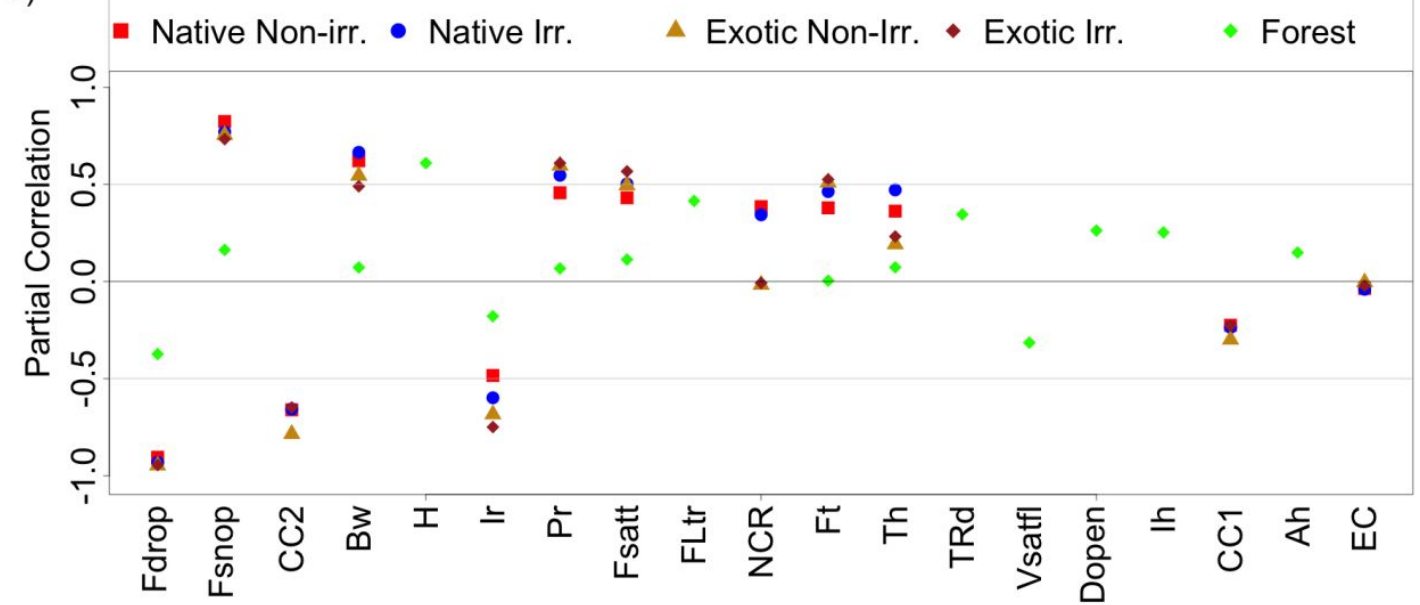

567

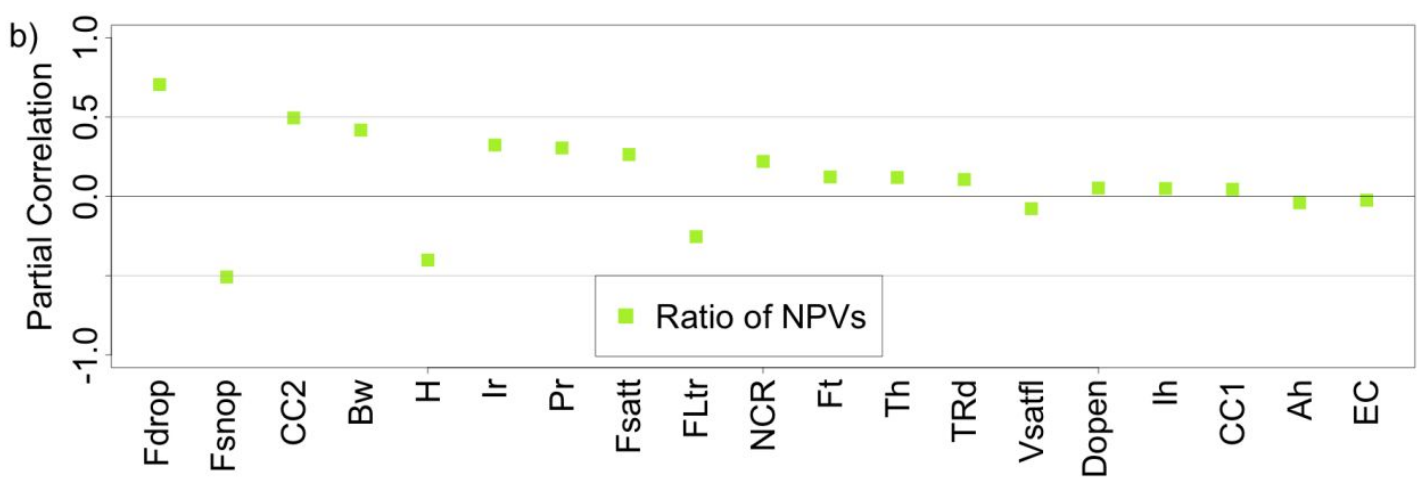

$568 \quad$ Figure 3.

569

570

571

572 


\section{References}

Allsopp, M. H., de Lange, W. J., \& Veldtman, R. (2008). Valuing Insect Pollination Services with Cost of Replacement. PLoS ONE, 3(9), e3128.

Bauer, D. M., \& Sue Wing, I. (2016). The macroeconomic cost of catastrophic pollinator declines. Ecological Economics, 126(Supplement C), 1-13.

Bhagwat, S. A., Kushalappa, C. G., Williams, P. H., \& Brown, N. D. (2005). A Landscape Approach to Biodiversity Conservation of Sacred Groves in the Western Ghats of India. Cons Biol, 19(6), 1853-1862.

Binswanger, H. P. (1980). Attitudes toward Risk: Experimental Measurement in Rural India. American Journal of Agricultural Economics, 62(3), 395-407. doi:10.2307/1240194

Boreux, V. (2010). An ecosystem service approach to coffee production in a complex landscape mosaic. ETH Zurich.

Boreux, V., Krishnan, S., Cheppudira, K. G., \& Ghazoul, J. (2013). Impact of forest fragments on bee visits and fruit set in rain-fed and irrigated coffee agro-forests. Agriculture Ecosystems \& Environment, 172, 42-48.

Boreux, V., Kushalappa, C. G., Vaast, P., \& Ghazoul, J. (2013). Interactive effects among ecosystem services and management practices on crop production: Pollination in coffee agroforestry systems. Proceedings of the National Academy of Sciences, 110(21), 8387-8392.

Bos, M. M., Veddeler, D., Bogdanski, A. K., Klein, A. M., Tscharntke, T., SteffanDewenter, I., \& Tylianakis, J. M. (2007). Caveats to quantifying ecosystem services: Fruit abortion blurs benefits from crop pollination. Ecological Applications, 17(6), 1841-1849.

Breeze, T. D., Gallai, N., Garibaldi, L. A., \& Li, X. S. (2016). Economic Measures of 
Pollination Services : Shortcomings and Future Directions. Trends in Ecology \& Evolution, 31(12), 927-939.

600

601

602

603

604

605

606

607

608

609

610

611

612

613

614

615

616

617

618

619

620

621

622

Burton, R. J. F. (2004). Reconceptualising the 'behavioural approach' in agricultural studies: a socio-psychological perspective. Journal of Rural Studies, 20(3), 359371. doi:https://doi.org/10.1016/j.jrurstud.2003.12.001

Butchart, S. H. M., Walpole, M., Collen, B., van Strien, A., Scharlemann, J. P. W., Almond, R. E. A., ... Watson, R. (2010). Global Biodiversity: Indicators of Recent Declines. Science, 328(5982), 1164 LP-1168.

Cardinale, B. J., Duffy, J. E., Gonzalez, A., Hooper, D. U., Perrings, C., Venail, P., ... Naeem, S. (2012). Biodiversity loss and its impact on humanity. Nature, 486(7401), 59-67.

Chan, K. M. A., Guerry, A. D., Balvanera, P., Klain, S., Satterfield, T., Basurto, X., ... Woodside, U. (2012). Where are $<$ em $>$ Cultural $</$ em $>$ and $<$ em $>$ Social $</$ em $>$ in Ecosystem Services? A Framework for Constructive Engagement. BioScience, 62(8), 744-756. doi:10.1525/bio.2012.62.8.7

Chan, K. M. A., Hoshizaki, L., \& Klinkenberg, B. (2011). Ecosystem Services in Conservation Planning: Targeted Benefits vs. Co-Benefits or Costs? PLoS ONE, 6(9), e24378.

Coffee Board. (2014). Coffee statistics. Retrieved from http://www.indiacoffee.org/\%28S\%2805xzugddendgxzbq5lwlgsxv\%29\%29/coff ee-statistics.html

Corlett, R. T. (2011). Honeybees in natural ecosystems. In H. R. Hepburn \& S. E. Radloff (Eds.), Honeybees of Asia (pp. 215-226). Berlin Heidelberg: SpringerVerlag .

De Beenhouwer, M., Aerts, R., \& Honnay, O. (2013). A global meta-analysis of the 
biodiversity and ecosystem service benefits of coffee and cacao agroforestry. Agriculture, Ecosystems \& Environment, 175(0), 1-7.

DeFries, R. S., Foley, J. A., \& Asner, G. P. (2004). Land-use choices: balancing human needs and ecosystem function. Frontiers in Ecology and the Environment, 2(5), 249-257. doi:10.1890/1540-9295(2004)002[0249:LCBHNA]2.0.CO;2

Díaz, S., Fargione, J., Chapin III, F. S., \& Tilman, D. (2006). Biodiversity Loss Threatens Human Well-Being. PLOS Biology, 4(8), e277.

Dyer, F. C., \& Seeley, T. D. (1991). Nesting Behavior and the Evolution of Worker Tempo in Four Honey Bee Species. Ecology, 72(1), 156-170.

Edwards-Jones, G. (2006). Modelling farmer decision-making: concepts, progress and challenges. Animal Science, 82(6), 783-790. doi:DOI: 10.1017/ASC2006112

FAOstat. (2018). FAOSTAT Database on Agriculture.

Frankel, R., \& Galun, E. (1977). Pollination mechanisms, reproduction and plant breeding. Berlin Heidelberg: Springer-Verlag.

French Institute of Pondicherry. (2012). Managing biodiversity in mountain landscapes. Linking forestry, agorforestry and livelihoods in the Western Ghats. Pondicherry, India. Retrieved from http://www.ifpindia.org/managingbiodiversity-in-mountain-landscapes.html

Garcia, C. A., Bhagwat, S. A., Ghazoul, J., Nath, C. D., Nanaya, K. M., Kushalappa, C. G., ... Vaast, P. (2010). Biodiversity conservation in agricultural landscapes: challenges and opportunities of coffee agroforests in the Western Ghats, India. Conserv Biol, 24(2), 479-488.

ICO. (2014). International Coffee Organization. Historical data.

Jones, R. (2005). Bibliography of Commonwealth Apiculture. (C. Secretariat, Ed.). London, UK. 
648 Kleijn, D., Winfree, R., Bartomeus, I., Carvalheiro, L. G., Henry, M., Isaacs, R., ... 649 Potts, S. G. (2015). Delivery of crop pollination services is an insufficient 650 argument for wild pollinator conservation. Nat. Commun., 6, 7414.

651 Klein, A.-M., Steffan-Dewenter, I., \& Tscharntke, T. (2003). Bee pollination and fruit set of Coffea arabica and C. canephora (Rubiaceae). American Journal of Botany, 90(1), 153-157.

Klein, A.-M., Vaissière, B. E., Cane, J. H., Steffan-Dewenter, I., Cunningham, S. A., Kremen, C., \& Tscharntke, T. (2007). Importance of pollinators in changing landscapes for world crops (Vol. 274).

Kremen, C., Williams, N. M., \& Thorp, R. W. (2002). Crop pollination from native 658 bees at risk from agricultural intensification. Proceedings of the National Academy of Sciences, 99(26), 16812-16816.

Krishnan, S. (2011). Pollinator services and coffee production in a forested landscape mosaic. ETH Zurich.

Krishnan, S., Kushalappa, C. G., Shaanker, R. U., \& Ghazoul, J. (2012). Status of 663 pollinators and their efficiency in coffee fruit set in a fragmented landscape mosaic in South India. Basic and Applied Ecology, 13(3), 277-285. provided by insects. Bioscience, 56, 311-323. from: Uncertainties in the value and opportunity costs of pollination services. Dryad Digital Repository. https://doi.org/10.5061/dryad.7f14jt7

670 Melathopoulos, A. P., Cutler, G. C., \& Tyedmers, P. (2015). Where is the value in 671 valuing pollination ecosystem services to agriculture? Ecological Economics, 109, 59-70. 
Meyfroidt, P., Carlson, K. M., Fagan, M. E., Gutiérrez-Vélez, V. H., Macedo, M. N., Curran, L. M., ... Robiglio, V. (2014). Multiple pathways of commodity crop expansion in tropical forest landscapes. Environ Res Lett, 9(7), 74012.

Moore, M. A., Boardman, A. E., Vining, A. R., Weimer, D. L., \& Greenberg, D. H. (2004). "Just give me a number!" Practical values for the social discount rate. Journal of Policy Analysis and Management, 23(4), 789-812.

Myers, N., Mittermeier, R. A., Mittermeier, C. G., da Fonseca, G. A. B., \& Kent, J. (2000). Biodiversity hotspots for conservation priorities. Nature, 403, 853-858.

Ninan, K. N., \& Inoue, M. (2013). Valuing forest ecosystem services: What we know and what we don't. Ecological Economics, 93, 137-149. doi:https://doi.org/10.1016/j.ecolecon.2013.05.005

Olander, L., Polasky, S., Kagan, J. S., Johnston, R. J., Wainger, L., Saah, D., ... Yoskowitz, D. (2017). So you want your research to be relevant? Building the bridge between ecosystem services research and practice. Ecosystem Services, 26, $170-182$.

Olschewski, R., Tscharntke, T., Benítez, P., Schwarze, S., \& Klein, A.-M. (2007). Economic evaluation of ecosystem services as a basis for stabilizing rainforest margins? The example of pollination services and pest management in coffee landscapes. In T. Tscharntke, C. Leuschner, M. Zeller, E. Guhardja, \& A. Bidin (Eds.), Stability of Tropical Rainforest Margins (pp. 263-276). Springer Berlin Heidelberg.

Paar, J., Oldroyd, B. P., Huettinger, E., \& Kastberger, G. (2004). Genetic Structure of an Apis dorsata Population: The Significance of Migration and Colony Aggregation. Journal of Heredity, 95(2), 119-126.

Pavageau, C., Gaucherel, C., Garcia, C., \& Ghazoul, J. (2018). Nesting sites of giant 
honey bees modulated by landscape patterns. Journal of Applied Ecology, 55, $1230-1240$.

Potts, S. G., Biesmeijer, J. C., Kremen, C., Neumann, P., Schweiger, O., \& Kunin, W. Evol, 25, 345-353.

Ricketts, T. H., Daily, G. C., Ehrlich, P. R., \& Michener, C. D. (2004). Economic value of tropical forest to coffee production. Proceedings of the National Academy of Sciences of the United States of America, 101(34), 12579-12582.

Rosenzweig, B., Cunningham, S., \& Wirthensohn, M. (n.d.). Almonds. Pollination Basics 101. (A. B. of Australia, Ed.).

Silvertown, J. (2018). Have Ecosystem Services Been Oversold? Trends in Ecology \& Evolution, 30(11), 641-648.

Vanbergen, A. J., \& The Insect Pollinators Initiative. (2013). Threats to an ecosystem service: pressures on pollinators. Frontiers in Ecology and the Environment,

Vandermeer, J., \& Perfecto, I. (2012). Intensification of coffee production and its biodiversity consequences. (D. Lindenmayer, S. Cunningham, \& A. Young, Eds.), Land Use Intensification: Effects on Agriculture, Biodiversity and Ecological Processes. Collingwood: Csiro Publishing.

Vergara, C. H., \& Badano, E. I. (2009). Pollinator diversity increases fruit production in Mexican coffee plantations: The importance of rustic management systems. Agriculture, Ecosystems \& Environment, 129(1-3), 117-123.

Winfree, R., Aguilar, R., Vázquez, D. P., LeBuhn, G., \& Aizen, M. A. (2009). A meta-analysis of bees' responses to anthropogenic disturbance. Ecology, 90(8), 2068-2076. 
723 Winfree, R., Gross, B. J., \& Kremen, C. (2011). Valuing pollination services to $724 \quad$ agriculture. Ecological Economics, 71(0), 80-88.

725 Wintgens, J. N. (2004). Coffee: growing, processing, sustainable production.

726 Weinheim, Germany: Wiley-Vch Verlag GmbH \& Co. KGaA.

727 World Agroforestry Centre, I. (2011). CAFNET project: Connecting, enhancing and

728 sustaining environmental services and market values of coffee agroforestry in 729 Central America, East Africa and India.

730 


\section{Uncertainties in the value and opportunity costs of pollination services}

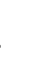

(1)

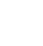

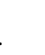

Ainhoa Magrach ${ }^{1,2,{ }^{*}}$, Antoine Champetier ${ }^{3, *}$, Smitha Krishnan ${ }^{1,4}$, Virginie Boreux $^{1,5}$ Jaboury Ghazoul ${ }^{1}$

${ }^{1}$ Ecosystem Management, Institute of Terrestrial Ecosystems, Department of

Environmental Systems Science, ETH Zürich, Universitätstrasse 16, 8092 Zürich,

Switzerland

${ }^{2}$ Basque Centre for Climate Change-BC3, Edif. Sede 1, $1^{\circ}$, Parque Tecnológico UPV, Barrio Sarriena s/n, 48940, Leioa, Spain +34 944014690 ext 168

${ }^{3}$ Institute for Environmental Decisions, Department of Environmental Systems Science, ETH Zürich

${ }^{4}$ Ashoka Trust for Research in Ecology and the Environment (ATREE), Bangalore 560064, India

${ }^{5}$ Department of Nature Conservation and Landscape Ecology, University of Freiburg, Tennenbacherstr. 4, 79106 Freiburg, Germany

*These authors contributed equally

${ }^{\text {a }}$ Corresponding author

Ainhoa Magrach ainhoamagrach@hotmail.com

Antoine Champetier antoinechampetier@gmail.com

Smitha Krishnan smithakrishnan@gmail.com

Virginie Boreux virginie.boreux@nature.uni-freiburg.de

Jaboury Ghazoul jaboury.ghazoul@env.ethz.ch

\section{Keywords}

Coffee, crop pollination, ecosystem services, forest, opportunity cost, sensitivity analysis, valuation 
37

\begin{tabular}{|c|c|c|c|}
\hline Parameter & $\begin{array}{l}\text { Coefficient of } \\
\text { variation }\end{array}$ & $\begin{array}{l}\text { Partial rank correlation } \\
\text { coefficients }\end{array}$ & $\begin{array}{l}\text { Absolute value of } \\
\text { PRCC }\end{array}$ \\
\hline $\mathrm{EC}$ & 0.25 & -0.0001 & 0.0001 \\
\hline $\mathrm{CC} 1$ & 0.25 & -0.0245 & 0.0245 \\
\hline $\mathrm{CC} 2$ & 0.25 & -0.0232 & 0.0232 \\
\hline NCR & 0.26 & -0.0477 & 0.0477 \\
\hline Ir & 0.20 & 0.0040 & 0.0040 \\
\hline $\operatorname{Pr}$ & 0.10 & 0.0186 & 0.0186 \\
\hline Th & 0.08 & -0.0225 & 0.0225 \\
\hline $\mathrm{Ft}$ & 0.08 & -0.0183 & 0.0183 \\
\hline Fsatt & 0.3 & -0.0003 & 0.0003 \\
\hline Fsnop & 0.35 & 0.0733 & 0.0733 \\
\hline $\mathrm{Bw}$ & 0.14 & 0.0246 & 0.0246 \\
\hline Fdrop & 0.46 & -0.1448 & 0.1448 \\
\hline $\mathrm{H}$ & 0.67 & 0.2254 & 0.2254 \\
\hline Ih & 0.22 & 0.1065 & 0.1065 \\
\hline $\mathrm{Ah}$ & 0.18 & 0.0031 & 0.0031 \\
\hline TRd & 0.29 & 0.0916 & 0.0916 \\
\hline Dopen & 0.25 & 0.0834 & 0.0834 \\
\hline FLtr & 0.42 & 0.0905 & 0.0905 \\
\hline Vsatfl & 0.29 & -0.0476 & 0.0476 \\
\hline
\end{tabular}

38

39

Table S1. Coefficients of variation and partial rank correlation coefficients of input 40

41 parameters for the ratio model output.

42

43

44 
45

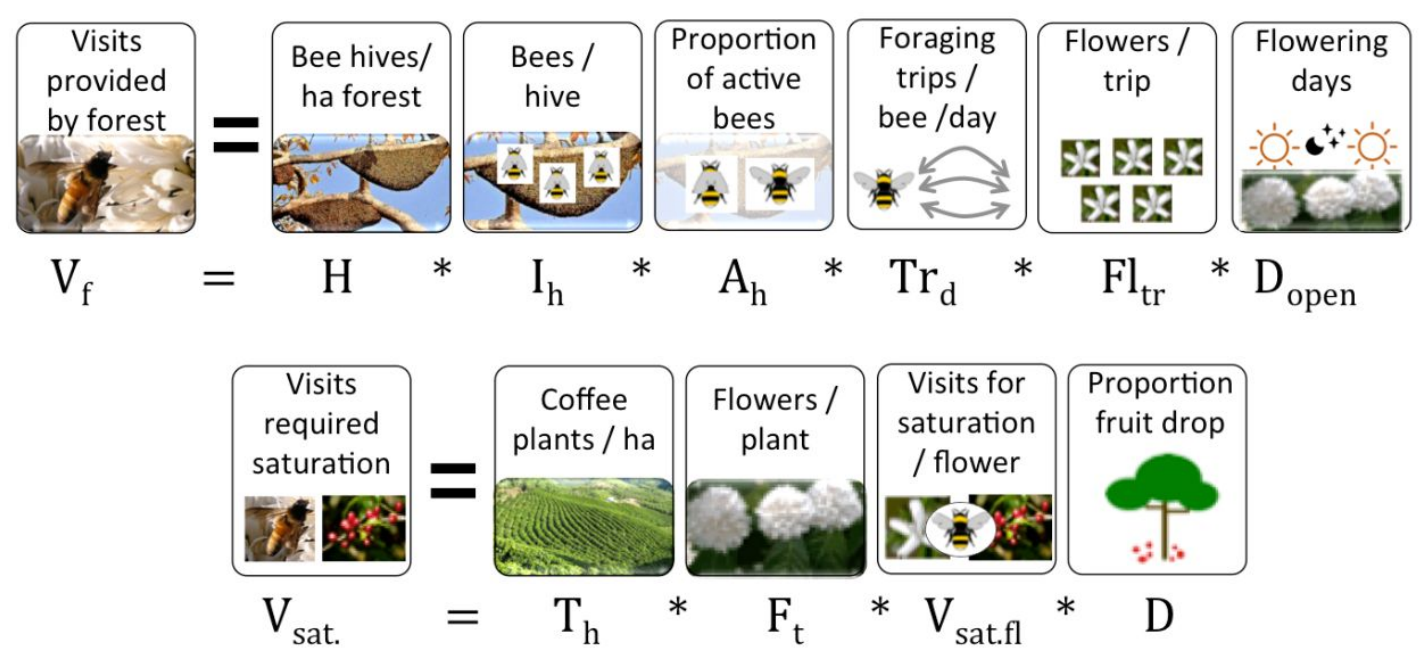

Figure S1. Schematic representation of the pathway followed to calculate $V_{f}$, the total

48 number of visits provided by Apis dorsata bees per hectare of forest to neighboring

49 coffee plantations and $\mathrm{V}_{\text {sat. }}$, the number of pollination visits required to reach

50 saturation yield in one hectare of coffee plantation.

51

52 


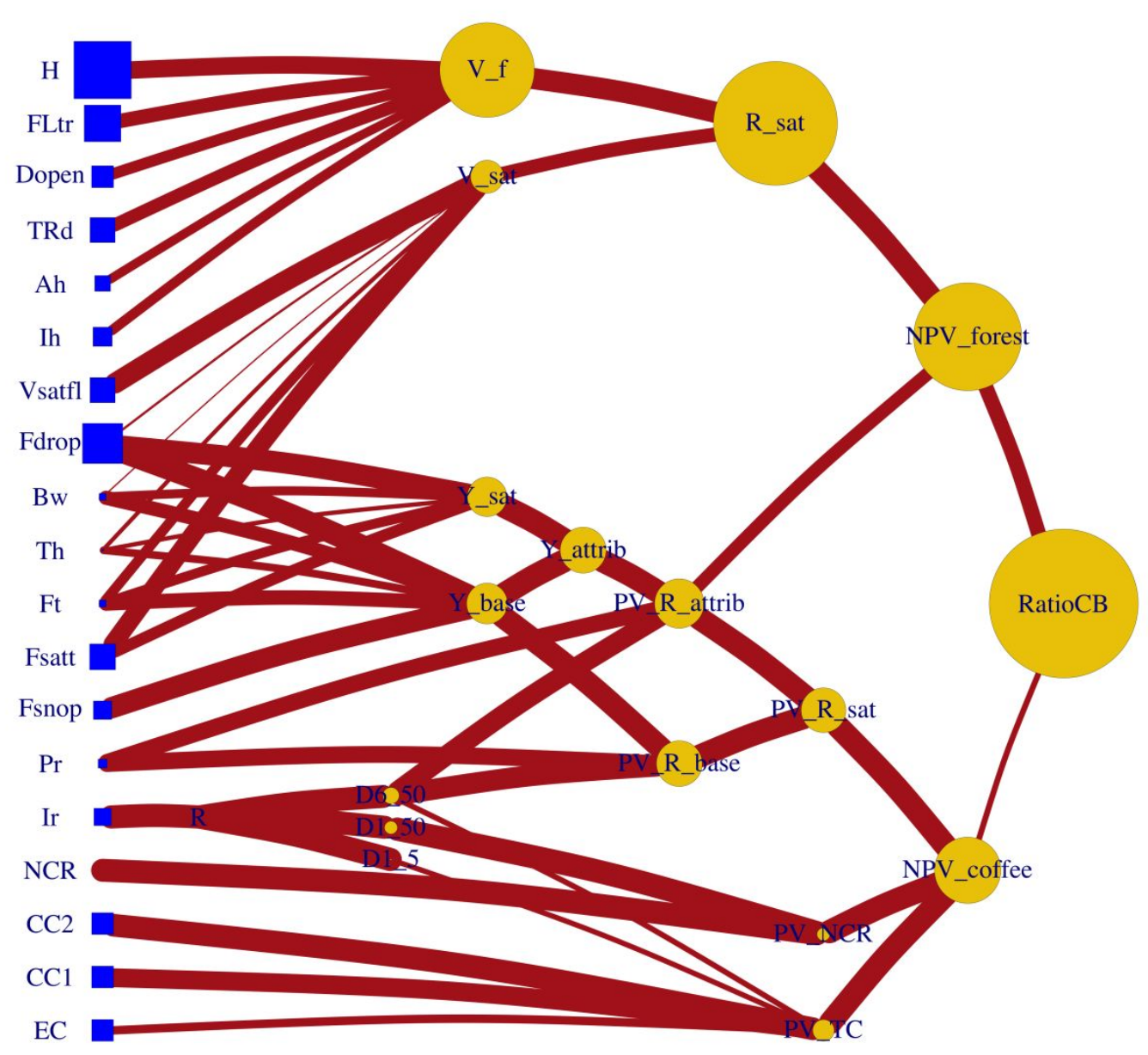

Figure S2. The square nodes on the tree represent parameters while the round ones represent calculations (or model variables). The names of the nodes refer to the parameters and variables listed in Table 1 and 2 and the size of the squares or circles represent the coefficient of variation of each element. The vertices or links connecting the parameters or variables represent the calculation steps and their width represents the contribution of each antecedent to a variable (measured in partial rank correlation coefficients). Calculations go from left to right. This figure corresponds to the exotic

61 irrigation coffee scenario. 


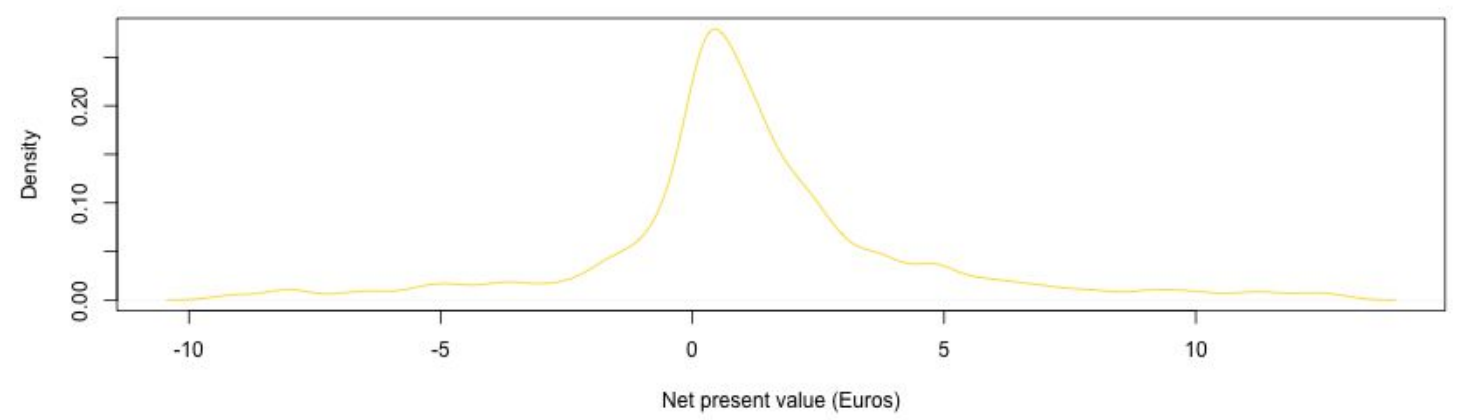

Figure S3. Density of the simulated distribution of ratio of forest to coffee NPV. 
$\bar{\circ}$

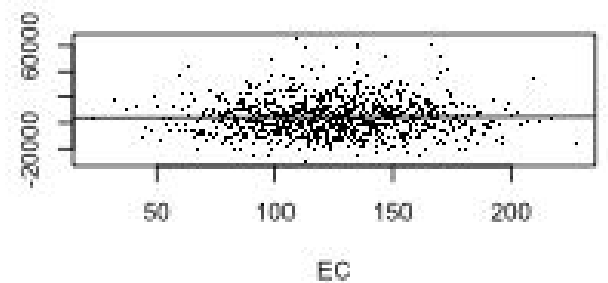

$\overline{0}$
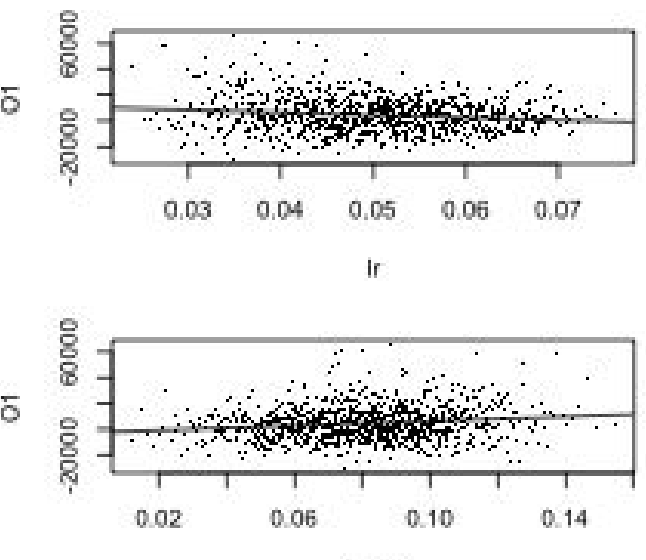

Fsatt

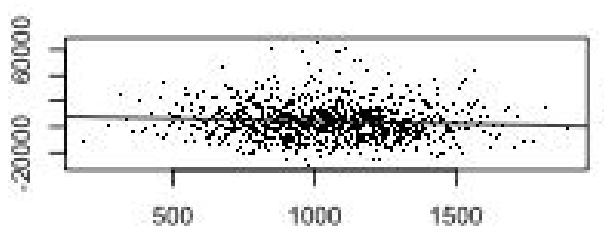

○) 1

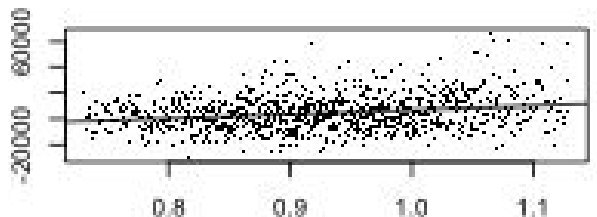

Pr

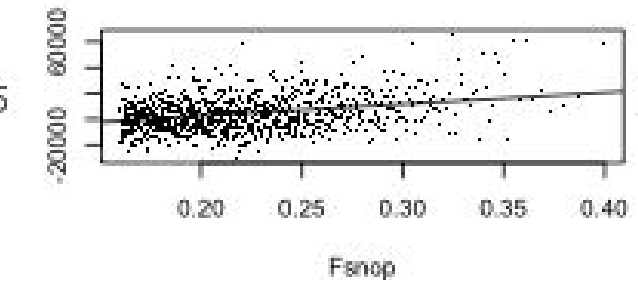

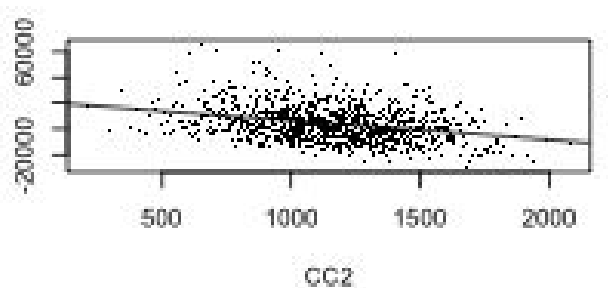
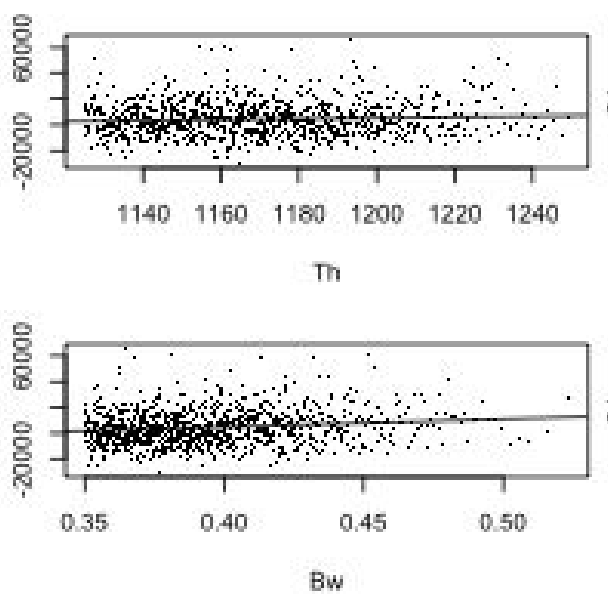
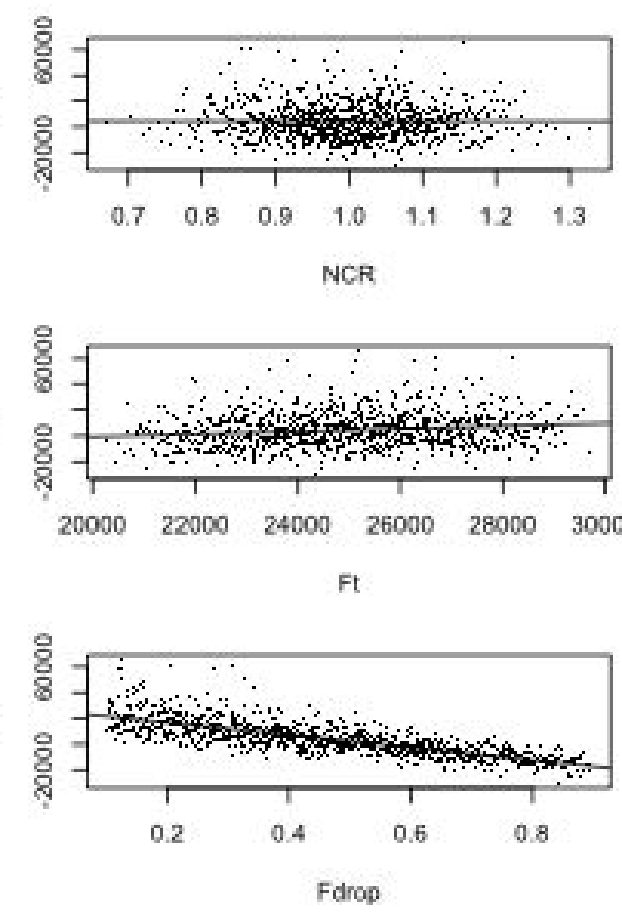

72 Figure S4 Scatterplots of outputs as a function of input factors: Exotic No-Irrigation 
ธ

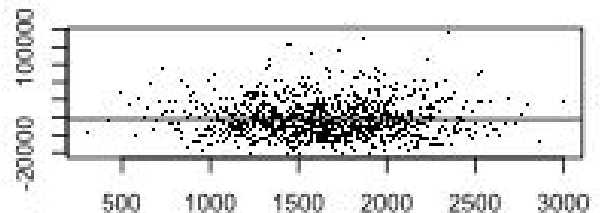

EC

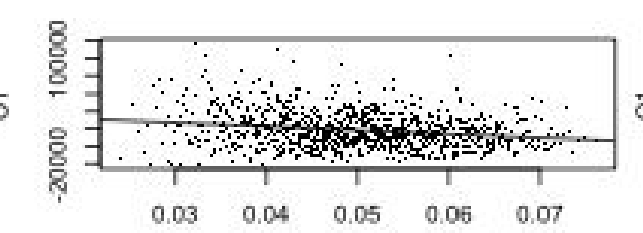

Ir

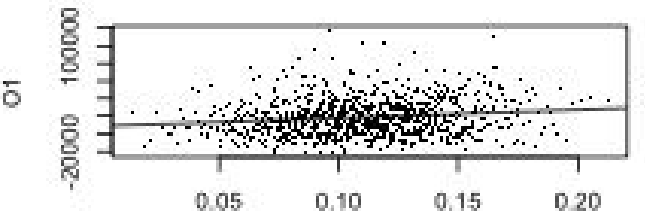

Fsatt
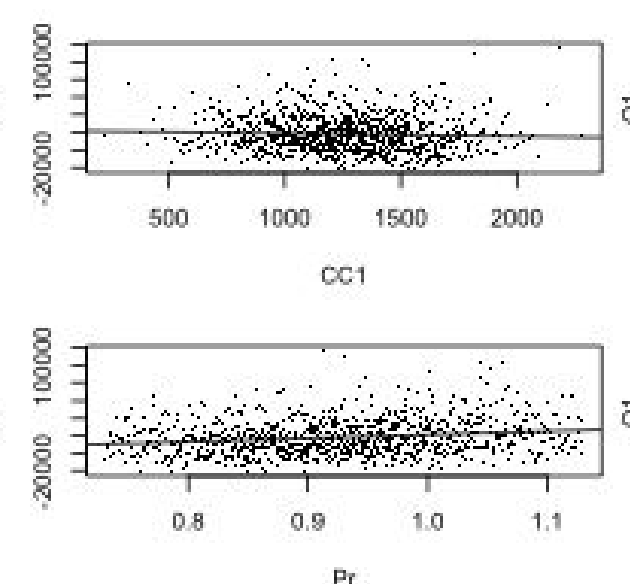

Pr

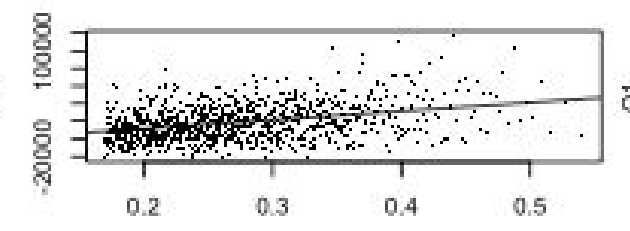

Frnop
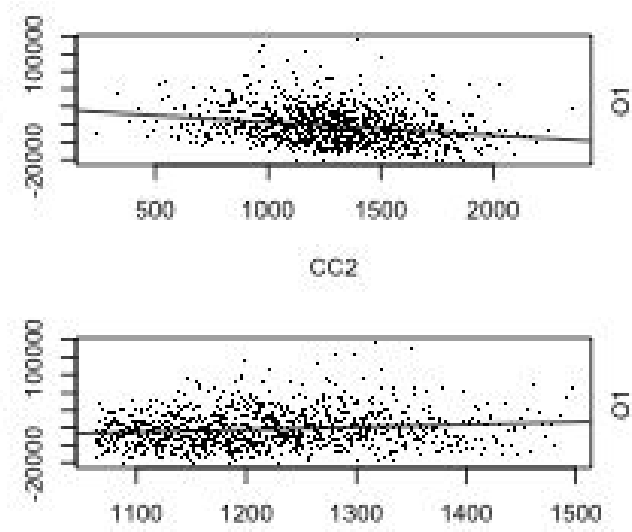

Th

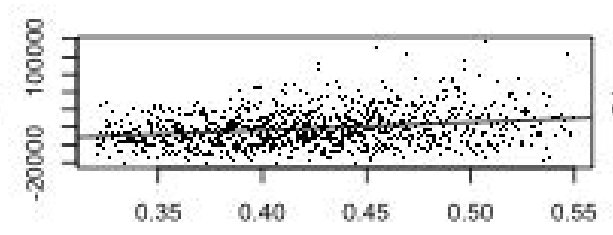

Bw
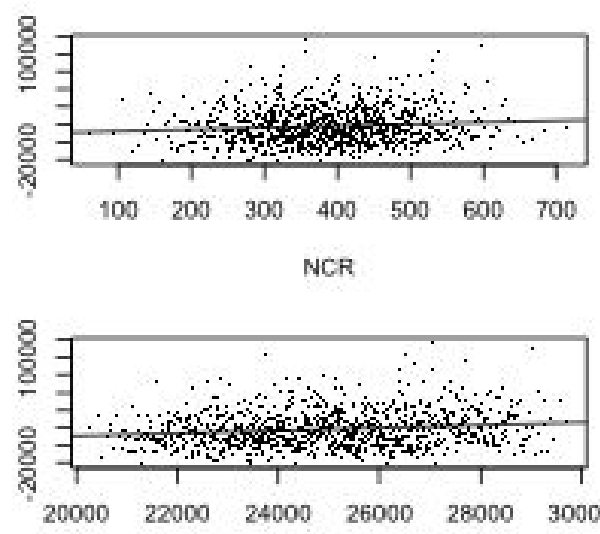

$\mathrm{Ft}$

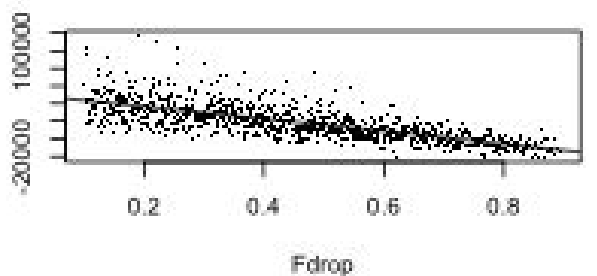

Figure S5 Scatterplots of outputs as a function of input factors: Native No-Irrigation 
$\overline{0}$

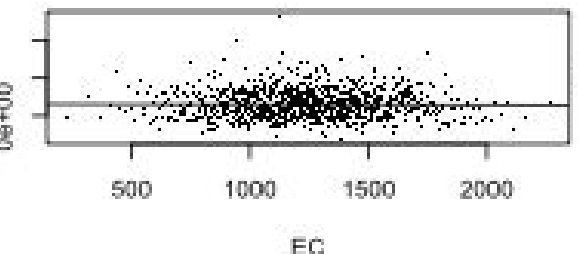

$\bar{\sigma}$
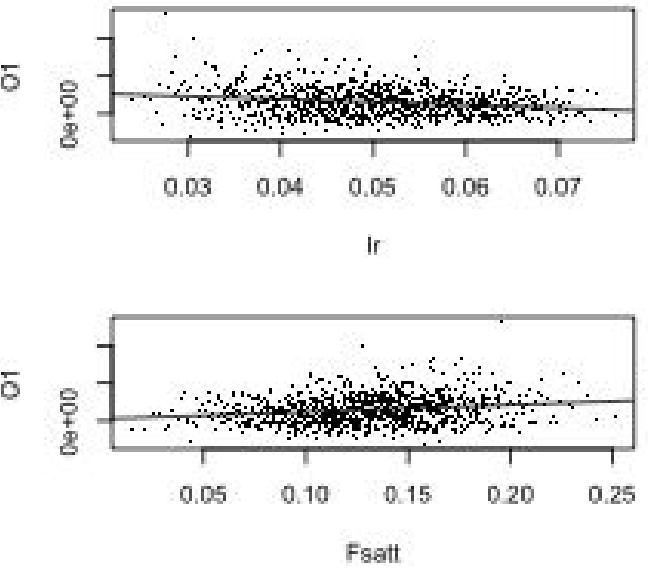

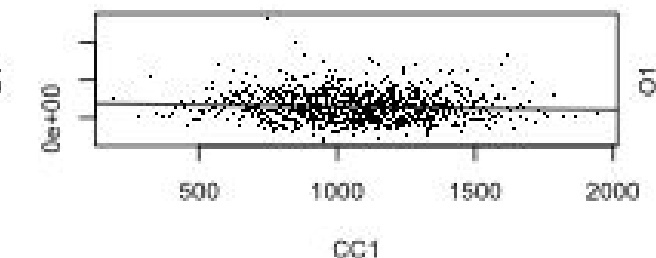

$\infty \mathrm{C} 1$

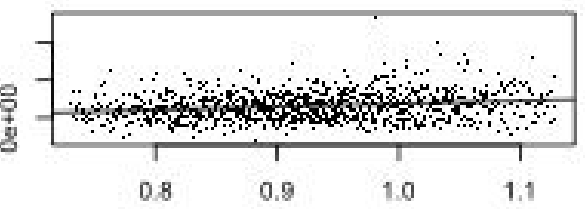

Pr

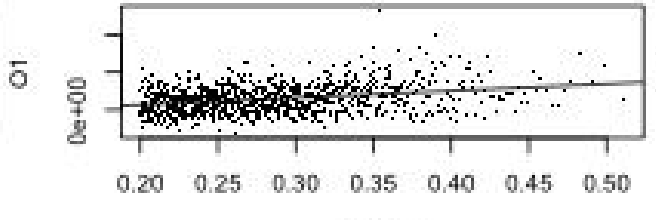

Fsnop
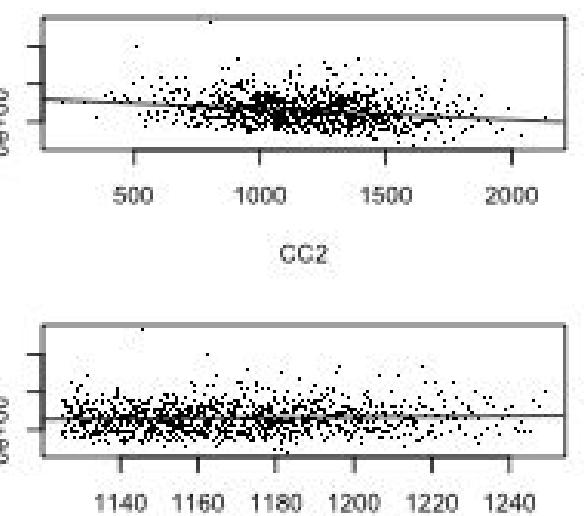

Th

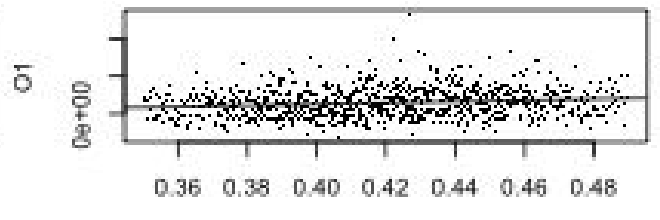

Bw
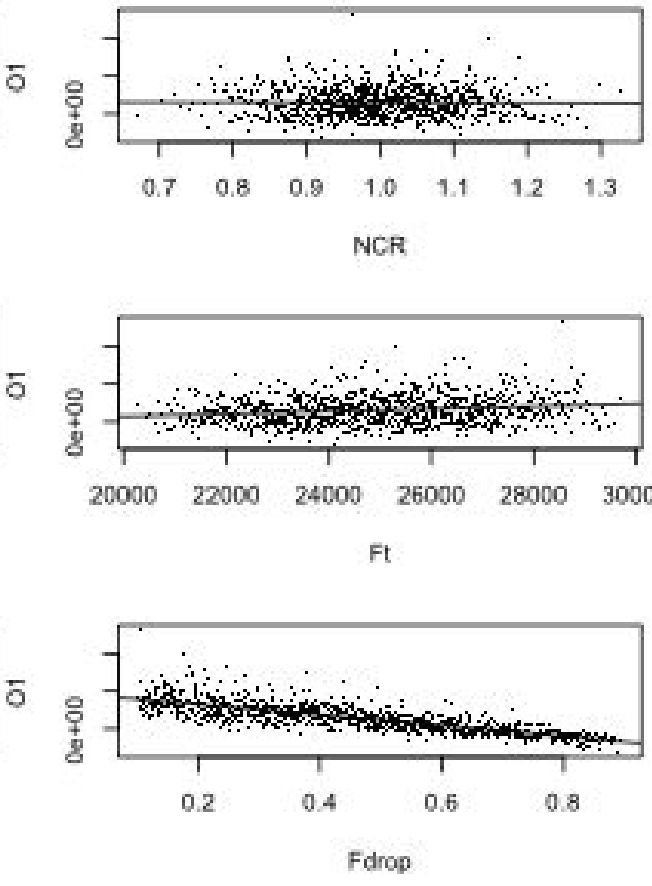

79 Figure S6 Scatterplots of outputs as a function of input factors: Exotic Irrigation 
5

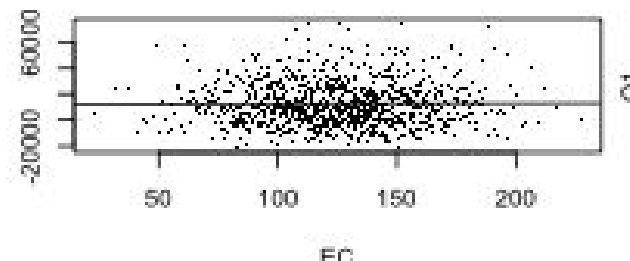

ธ

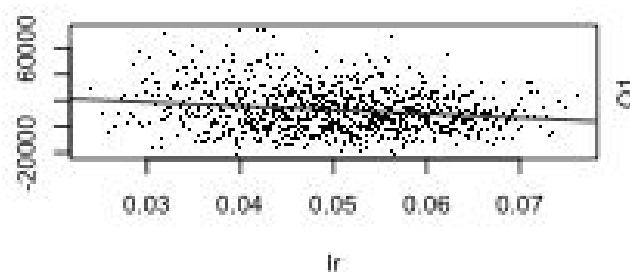

$\bar{o}$

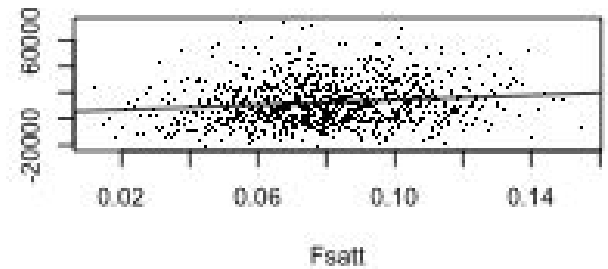

$\overline{0}$

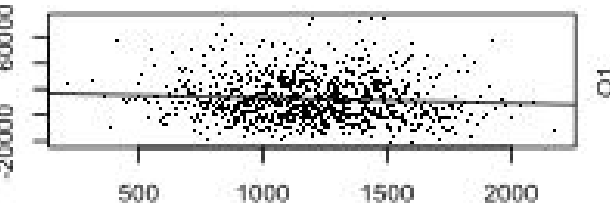

$\infty \mathrm{C} 1$

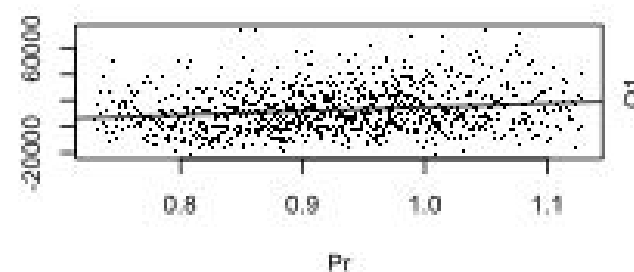

$\operatorname{Pr}$

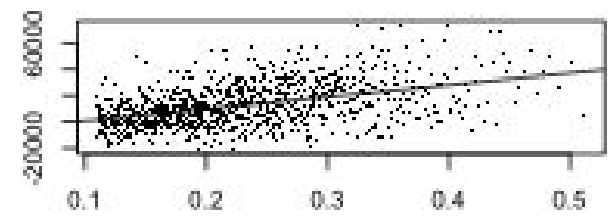

Frnop
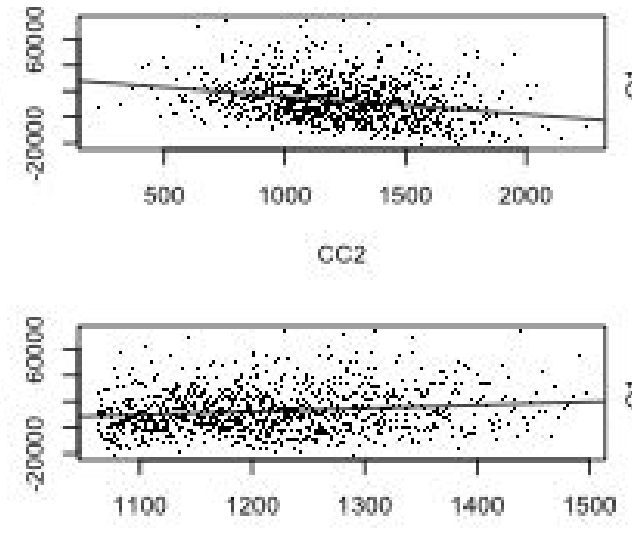

$\mathrm{T}$

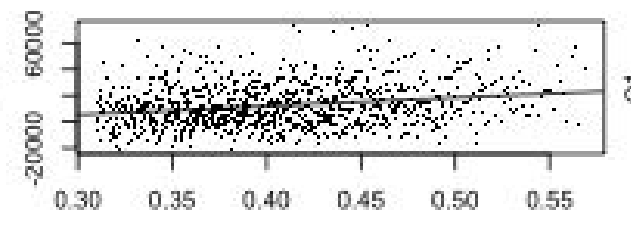

Bw

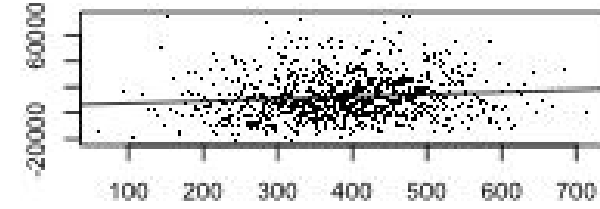

NCR
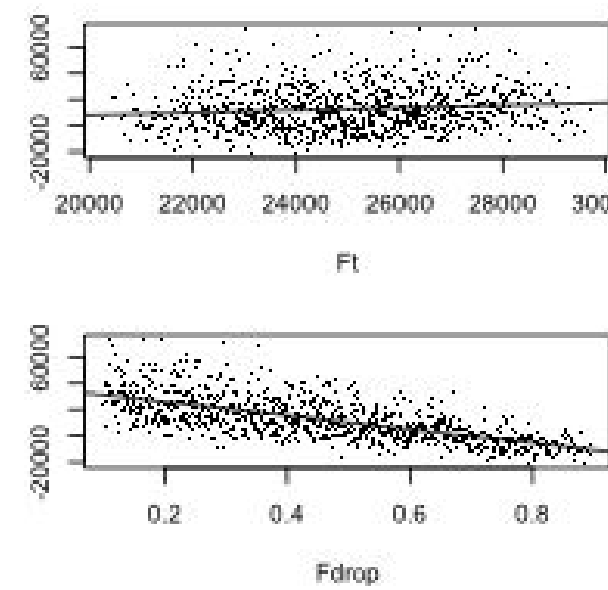

82 Figure S7 Scatterplots of outputs as a function of input factors: Native Irrigation 

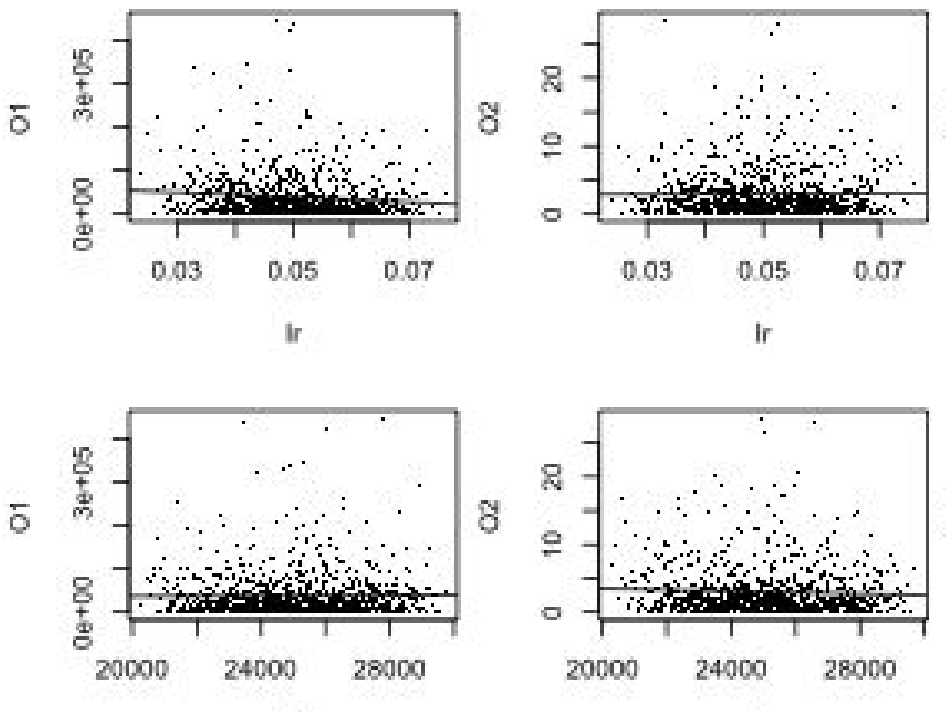

$\mathrm{Ft}$

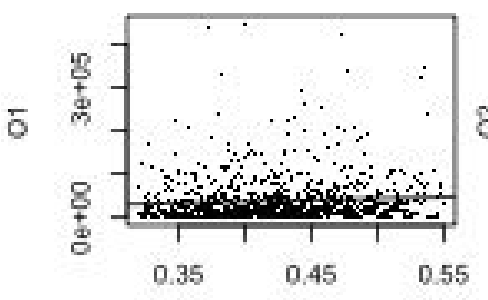

Bw

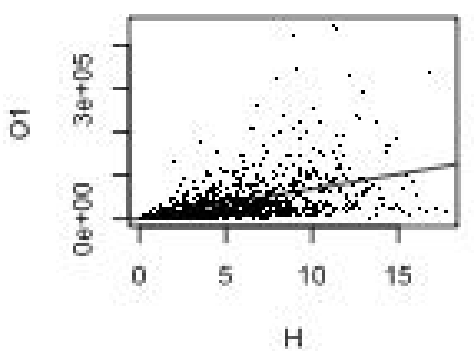

H

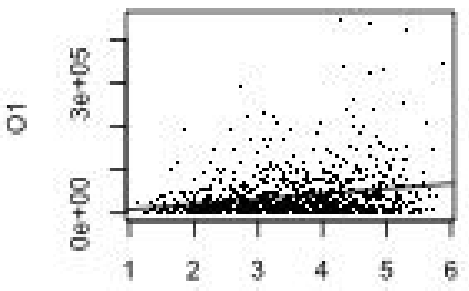

TRd
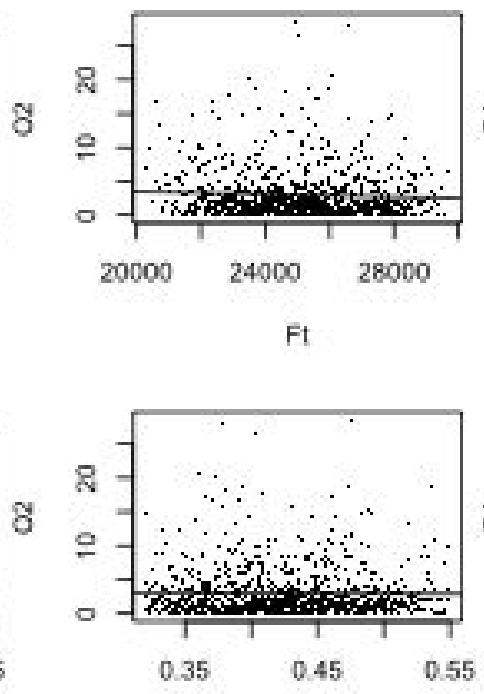

Bw

H

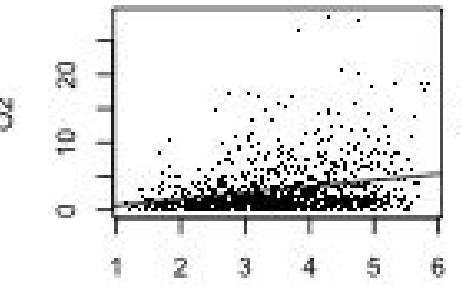

TRd
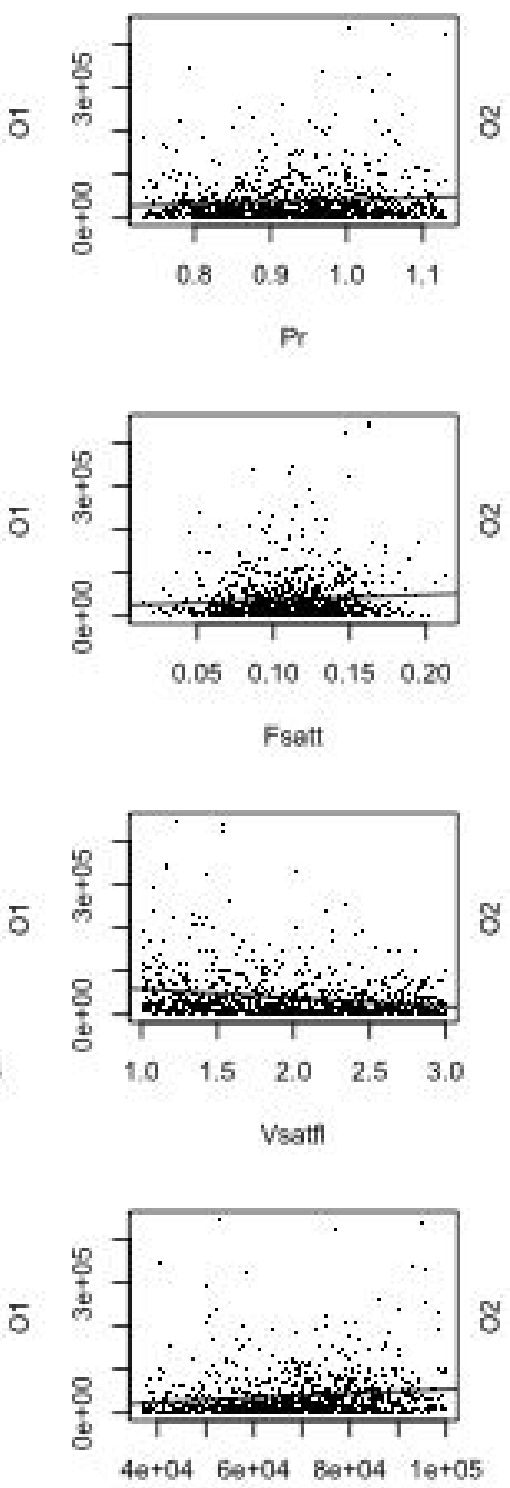

In

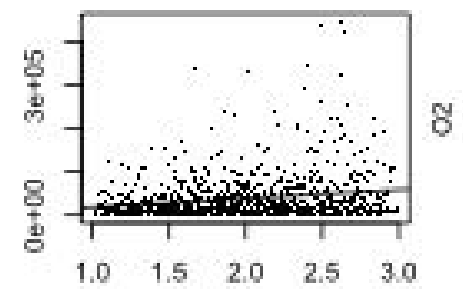

Dopen

86 Figure S8 Scatterplots of outputs as a function of input factors: Forest net present 87 value 

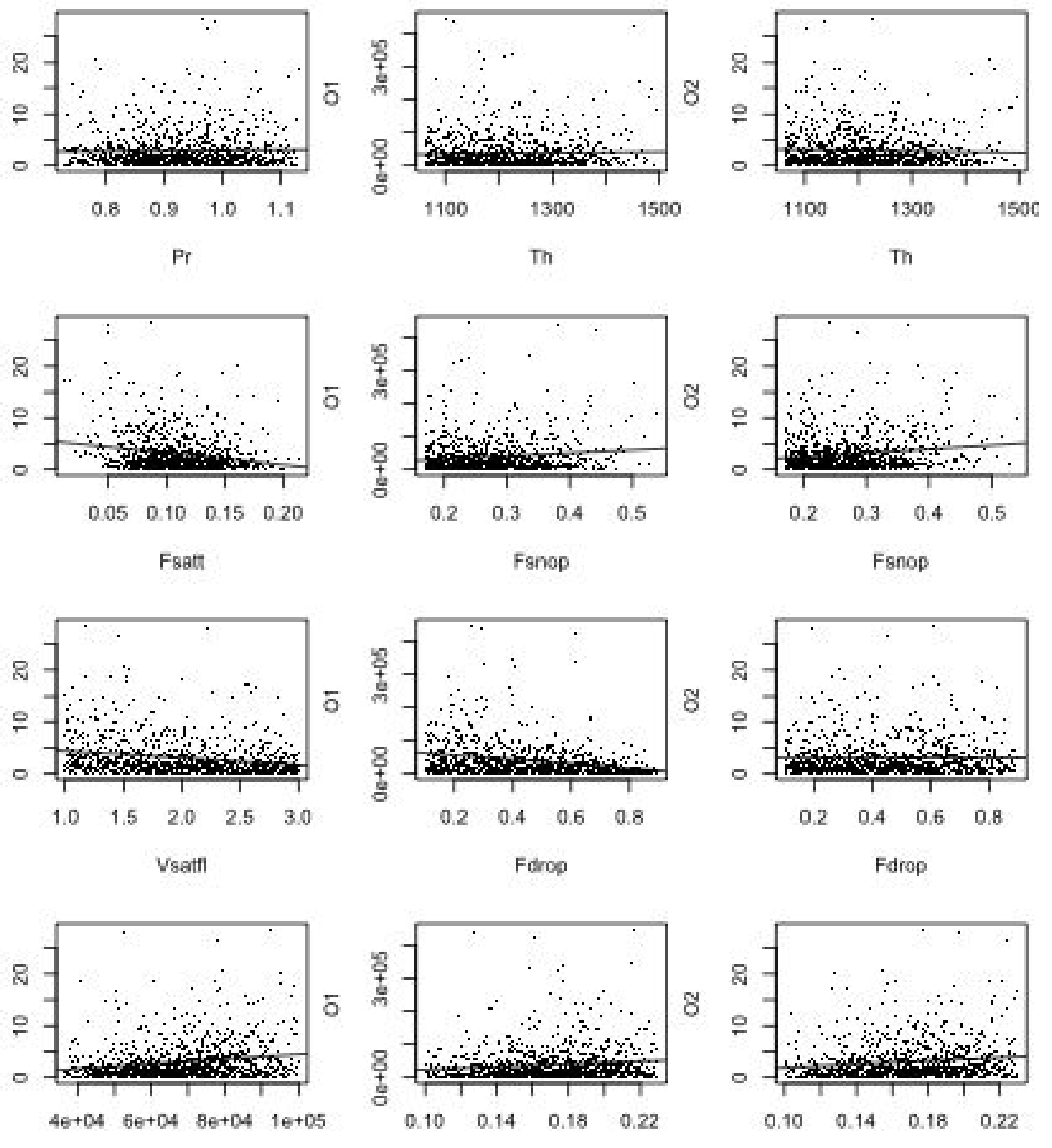

Ih

An

Ah
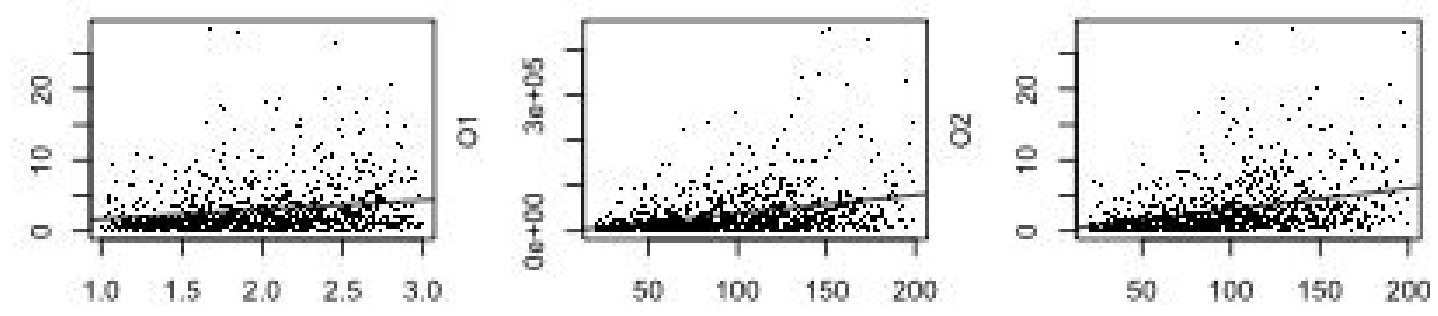

FLtr

FLtr 

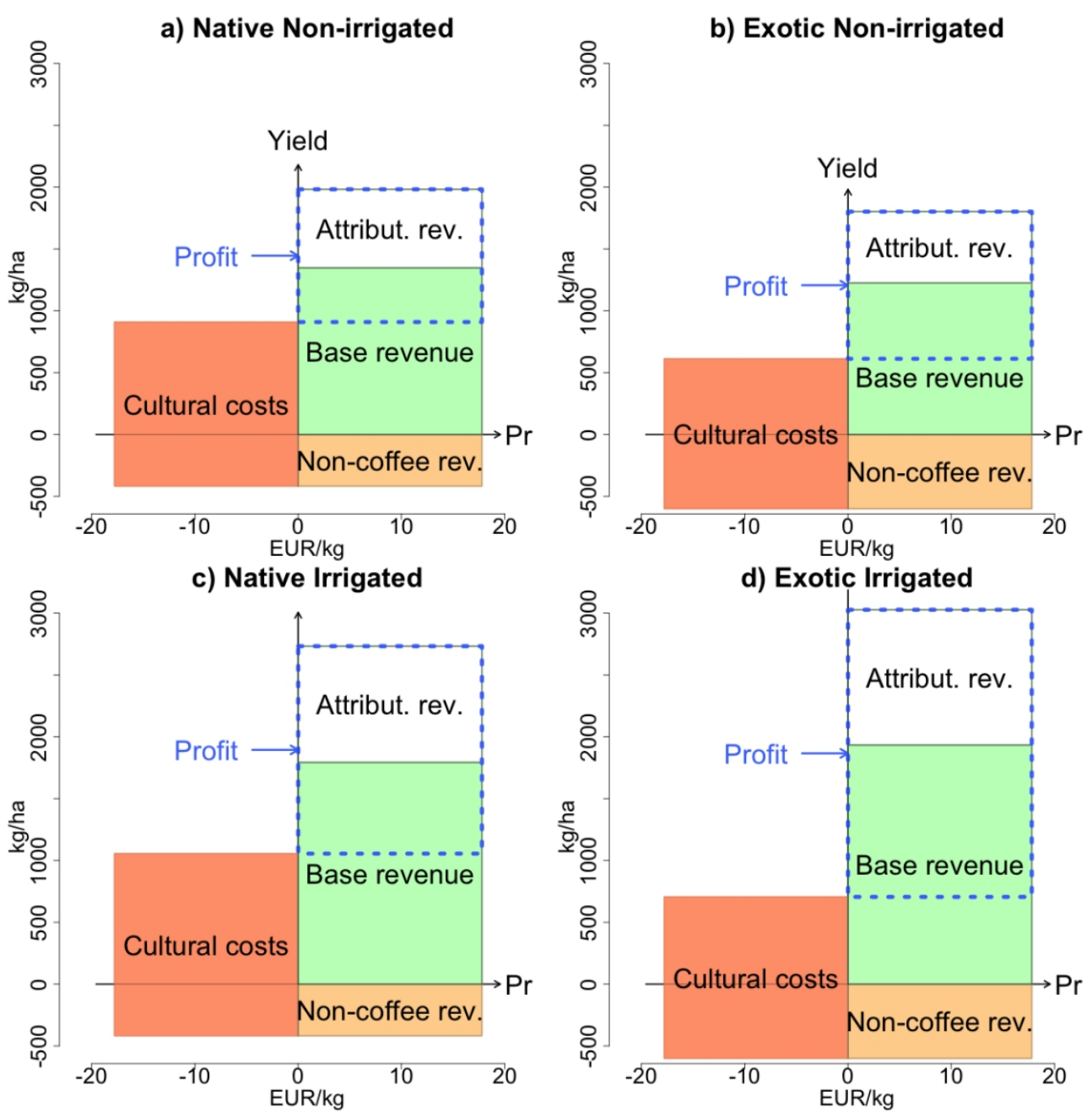

Figure 1. Diagram showing the relationships between coffee yields (both base in green, i.e., independent of pollinator activity, and those attributable to the effect of pollinator activity and hence dependent on the presence of forest ecosystems in white), prices, costs, profits and other accounting variables for a 50-year horizon of one hectare of coffee under four management regimes: under native canopy trees with and without irrigation (panels $a$ and $b$ ), or under $G$. robusta with and without irrigation ( $c$ and d). The horizontal axis references the price of coffee adjusted for discounting and the vertical is the yield ( $\mathrm{kg} / \mathrm{hectare} / \mathrm{year}$ after first five years). Areas on the graph represent net present value. Boxes in dashed blue lines represents profit. See procedures for detailed calculations. 


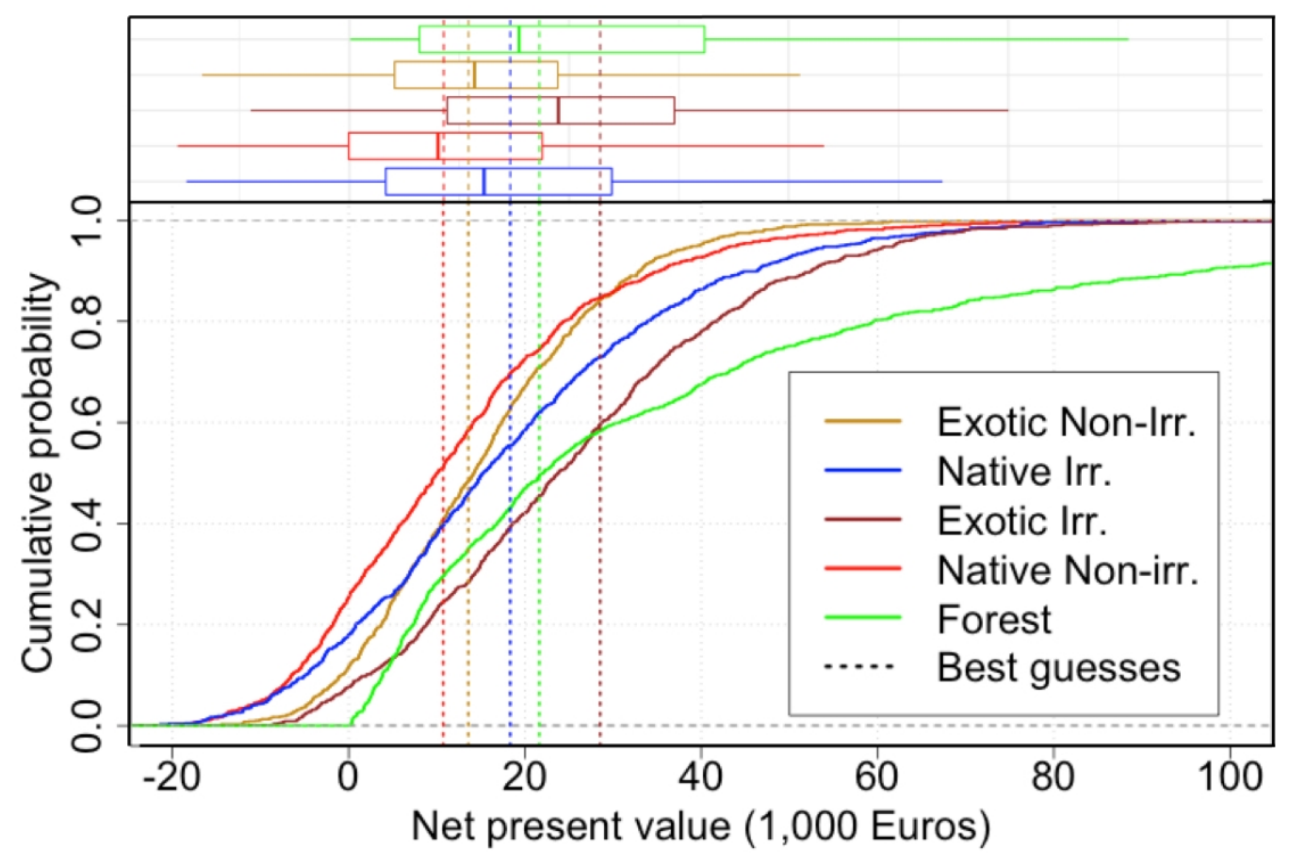

$432 \times 284 \mathrm{~mm}(72 \times 72$ DPI $)$ 
a)

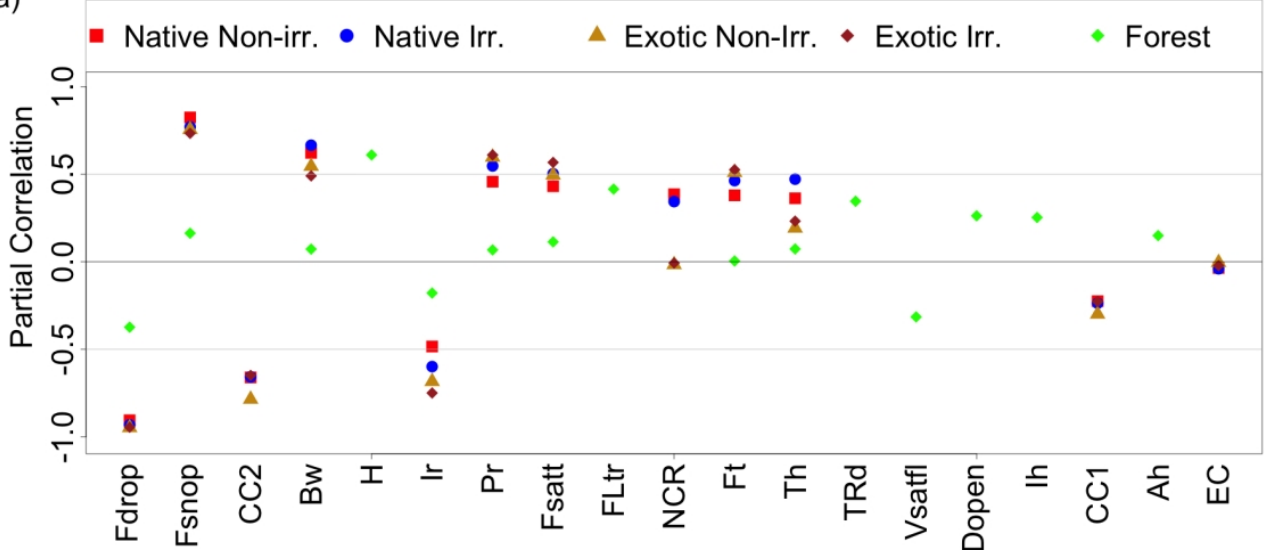

Figure 3. Partial rank correlation coefficients of model parameters for net present values (a) and ratio of net present values (b).

Fruit drop (Fdrop), fruit set without pollination (Fsnop),cultural costs for years six to 50 when coffee becomes productive (CC2), berry weight (Bw), hive density per hectare $(\mathrm{H})$, price of coffee (Pr), interest rate (Ir), flowers per tree (FLtr), number of coffee trees/ha (Th), fruit set attributable to pollination (Fsatt), revenues from pepper and othe non-coffee products (NCR), number of flowers/tree (Ft), number of visits required to saturate one flower (Vsatfl), trips per day (TRd), days during which flowers are open (Dopen), cultural costs for the first five years when coffee is not yet productive (CC1), Number of individuals in Apis dorsata hives (Ih), individuals of a colony foraging at a given moment (Ah), establishment costs (EC) 


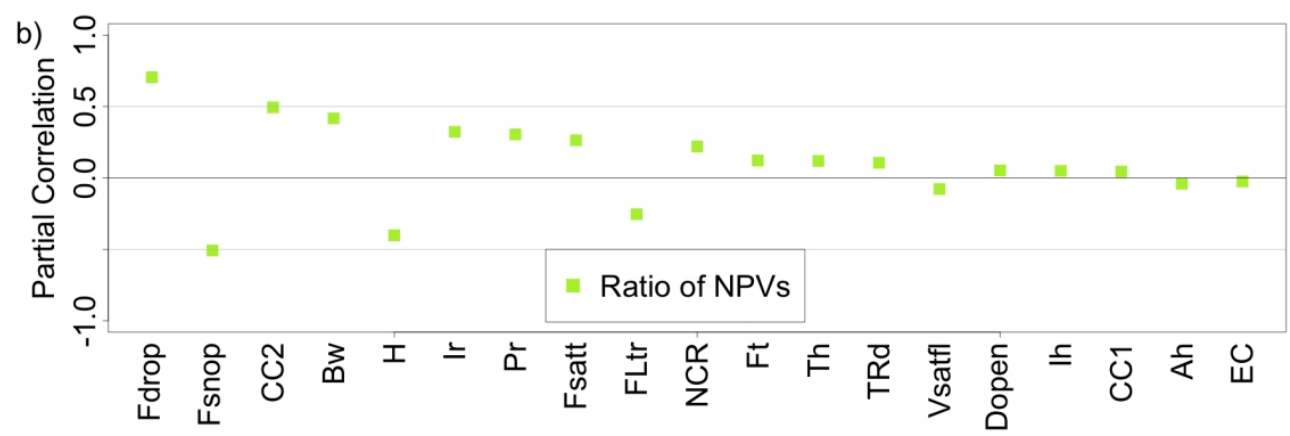

$635 \times 211 \mathrm{~mm}(72 \times 72 \mathrm{DPI})$ 